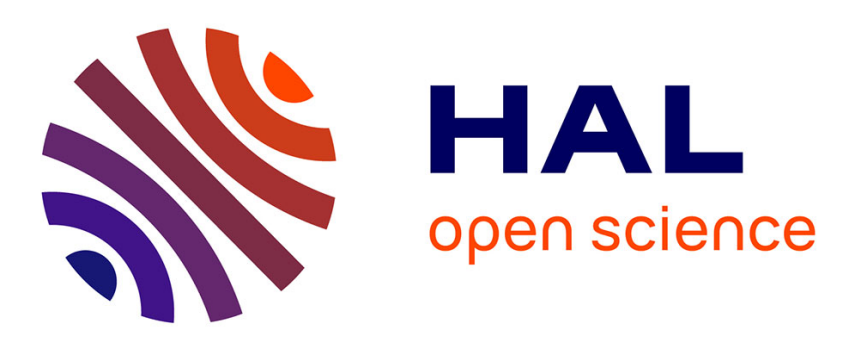

\title{
Rare earth element input and transport in the near-surface zonal current system of the Tropical Western Pacific
}

Melanie K Behrens, Katharina Pahnke, Sophie Cravatte, Frédéric Marin, Catherine Jeandel

\section{To cite this version:}

Melanie K Behrens, Katharina Pahnke, Sophie Cravatte, Frédéric Marin, Catherine Jeandel. Rare earth element input and transport in the near-surface zonal current system of the Tropical Western Pacific. Earth and Planetary Science Letters, 2020, 549, pp.116496. 10.1016/j.epsl.2020.116496 . hal-03060029

\section{HAL Id: hal-03060029 \\ https://cnrs.hal.science/hal-03060029}

Submitted on 13 Dec 2020

HAL is a multi-disciplinary open access archive for the deposit and dissemination of scientific research documents, whether they are published or not. The documents may come from teaching and research institutions in France or abroad, or from public or private research centers.
L'archive ouverte pluridisciplinaire HAL, est destinée au dépôt et à la diffusion de documents scientifiques de niveau recherche, publiés ou non, émanant des établissements d'enseignement et de recherche français ou étrangers, des laboratoires publics ou privés. 
1 Rare earth element input and transport in the near-surface zonal current system of the

2 Tropical Western Pacific

3

4 Melanie K. Behrens ${ }^{\mathrm{a}^{*}}$, Katharina Pahnke ${ }^{\mathrm{a}}$, Sophie Cravatte ${ }^{\mathrm{b}}$, Frédéric Marin ${ }^{\mathrm{b}}$, Catherine

5 Jeandel $^{\mathrm{b}}$

$6{ }^{a}$ Marine Isotope Geochemistry, Institute for Chemistry and Biology of the Marine

7 Environment (ICBM), University of Oldenburg, Carl-von-Ossietzky-Str. 9-11, 26129

8 Oldenburg, Germany (*corresponding author: melanie.behrens@uni-oldenburg.de)

9 bLEGOS, Université de Toulouse, (IRD, CNES, CNRS, UPS), Toulouse, France

11 Keywords: Rare earth elements; zonal current system; GEOTRACES

13 Abstract

14 Continental sources and current transport play a major role in rare earth element (REE, and

15 other trace element) input and distribution in the Tropical Western Pacific. Here, we present

16 spatially highly resolved distributions of dissolved REE concentrations ([REE]) along three

17 transects in the zonal (extra-)equatorial current system and the Solomon Strait of the Tropical

18 Western Pacific. We use seawater [REE] in combination with direct physical oceanographic

19 observations (e.g., current velocity data) to characterize the geochemical composition, origin

20 and pathways of the complex surface and upper layer currents of the Tropical Western Pacific

21 and to quantify the input fluxes of REEs. We identify Papua New Guinea (PNG) volcanic

22 rocks, sediments, and/or river particles as the key source adding trace elements to the

23 equatorial eastward zonal currents of the Tropical Western Pacific. Our and published data

24 indicate temporal and spatial variability of this input and transport in the PNG source area

25 and the equatorial eastward currents. The westward currents, on the other hand, lack this REE 
26 input signal suggesting lateral transport of preformed seawater [REE]. At the transition

27 between these zonal eastward and westward currents, our data indicate lateral mixing of

28 Eastern and Western Pacific source waters.

\section{Introduction}

31 Previous studies from the Tropical Western Pacific pointed out that the supply of 32 micronutrients (e.g., iron, Fe) and other trace elements (e.g., rare earth elements (REE)) in 33 this region likely occurs through fluxes from volcanic island margins such as Papua New 34 Guinea (PNG) and active river input, particularly from the Sepik River (Sholkovitz et al., 35 1999; Lacan and Jeandel, 2001, 2005; Radic et al., 2011; Slemons et al., 2010, 2012; Grenier 36 et al., 2013, 2014; Labatut et al., 2014; Behrens et al., 2018a; Pham et al., 2019) (Fig. 1a). 37 This was first recognized by Lacan and Jeandel (2001), who suggested that exchange fluxes 38 between PNG margin sediments and adjacent seawater are a source of trace element input to 39 the tropical Pacific zonal current system. Grenier et al. (2013) identified other areas of 40 lithogenic input in the Tropical Western Pacific (e.g., New Ireland, Solomon Islands, 41 Vanuatu, Fiji, Tonga, Samoa) and observed that these fluxes along volcanic island margins 42 can occur throughout the entire water column. In addition, the recent studies of Behrens et al. 43 (2018a, b) and Pham et al. (2019) reported additional areas of seawater REE enrichments 44 near the Philippine Islands in the tropical Northwest Pacific and within the Straits of the 45 Solomon Sea, respectively. Labatut et al. (2014) further suggested net dissolved Fe input 46 through particulate-dissolved exchange processes near PNG that may be of the same nature 47 as those proposed for other particle reactive elements such as REEs, making REEs an ideal

48 tracer for trace element fluxes in our study area.

49 The relative concentrations of individual dissolved REEs in the ocean are determined by the 50 strength of complexation by carbonate ions that increases from light REEs (LREEs) to heavy 
51 REEs (HREEs), resulting in a preferential removal of LREEs over HREEs from seawater

52 (e.g., Byrne and Kim, 1990). Seawater REE patterns are therefore characterized by a typical

53 fractionation pattern with an HREE over LREE enrichment (e.g., Elderfield and Greaves,

54 1982). This characteristic fractionation pattern is visualized by normalization of seawater

55 [REE] to those of a reference water mass or a terrestrial reference standard such as the Post

56 Archean Australian Shale (PAAS) (Taylor and McLennan, 1985). Deviations from this

57 typical REE pattern indicate input ('flat' PAAS-normalized REE pattern) or removal (high

58 PAAS-normalized HREE/LREE ratio) of REEs, or are characteristic of specific sources. In

59 particular, PAAS-normalized positive europium $(\mathrm{Eu})$ anomalies in seawater are characteristic

60 of volcanic input (e.g., Grenier et al., 2013; Molina-Kescher et al., 2018). Enrichments in

61 middle REEs (MREEs) point to river input related to weathering of phosphate minerals (e.g.,

62 Sholkovitz et al., 1999) or release from oxyhydroxides (Haley et al., 2004). REEs are thus

63 ideal to document trace element input, and in combination with direct physical oceanographic

64 observations, to characterize and quantify the geochemical composition, origin and transport

65 of water masses and currents within the ocean. The meridionally and latitudinally high-

66 resolution profiles of dissolved [REE] from the zonal current system of the Tropical Western

67 Pacific and the Solomon Strait presented here (Fig. 1a), provide insight into the small-scale

68 current transport, REE fluxes and lateral advection. In addition, direct combination of the

69 geochemical data with high-resolution physical observations from the same cruise allows the

70 first common detailed assessment of near-surface input and zonal current transport in this

71 region. Based on the combination of elemental concentration data with volume transport data,

72 we estimate element input fluxes and quantify the eastward transport of REE. Additionally,

73 we identify in detail the source areas and origin of the currents based on their distinct

74 Western and Eastern Pacific REE signatures. Moreover, we use published dissolved seawater

$75[\mathrm{REE}]$ and Fe concentration ([Fe]) data from the Tropical Western Pacific (including the 
76 Solomon Sea) (Obata et al., 2008; Slemons et al., 2010, 2012; Grenier et al., 2013; Behrens et 77 al., 2018a; Pham et al., 2019) to evaluate the temporal and spatial variability in this very 78 dynamic area.

\section{2. Study area and hydrography}

81 Our study area lies in the Tropical Western Pacific (Fig. 1a). During the CASSIOPEE cruise 82 with R/V L'Atalante (GEOTRACES compliant data GPc05) from July to August 2015, 10 stations were sampled along three transects at $152.5^{\circ} \mathrm{E}, 157.5^{\circ} \mathrm{E}$ and $165^{\circ} \mathrm{E}$ within the zonal current system (stations 14, 19, 24, 29, 47, 50, 54, 57, 66, 69) (Fig. 1a). Additionally, two

85 stations were sampled in the eastern and western parts of the Solomon Strait (stations 60 and 63, respectively) (Fig. 1a). Westward and eastward zonal currents were identified during the cruise using acoustic doppler current profiler (ADCP) data (Fig. 1a) (Delpech et al., 2019).

88 The near surface circulation $(\leq 100 \mathrm{~m}$ water depth) in the study area is usually dominated east 89 of the Solomon Sea by the westward flowing South Equatorial Current (SEC), weaker at the 90 equator where it can reverse during episodic westerly wind events (Reverdin et al., 1994). In 91 the Solomon Sea, the dominant feature is the surface New Guinea Coastal Current (NGCC) 92 western boundary current that flows along the PNG margin and exits the Solomon Sea 93 through Vitiaz Strait (e.g. Fine et al., 1994; Hristova and Kessler, 2012; Ganachaud et al., 94 2017). Surface flow is also entering the Solomon Sea through the Solomon Strait (stations 60, 95 63). The SEC is seasonally weaker during July-August, but the NGCC is stronger (Hristova 96 and Kessler, 2012; Cravatte et al., 2011).

97 During the CASSIOPEE cruise, the surface circulation was influenced by strong westerly 98 wind events occurring during the onset of El Niño conditions (Oceanic Niño Index, ONI, of $99+1.5$ to $+1.8$

100 https://origin.cpc.ncep.noaa.gov/products/analysis_monitoring/ensostuff/ONI_v5.php). These 
101

102

103

104

105

106

107

108

109

110

111

112

113

114

115

116

117

118

119

120

121

122

123

124

westerly winds forced eastward surface currents (SC) north of $2^{\circ} \mathrm{S}$, which advected surface water from the equatorial western Pacific eastward (Delpech et al., 2019; Fig. 1). During such conditions, surface waters are advected from the coast of PNG to the equator (Radenac et al., 2016). Stations 69, 47, 29 sampled these waters, whereas stations 14, 19, 54, 57, 66 sampled the westward SEC waters (Fig. 1). Stations 24 and 50 sampled the meridionally sheared transition zone between these eastward and the westward currents. In contrast, the sampling campaign during the EUC-Fe cruise (Aug.-Sept. 2006) took place during a weak El Niño event $(\mathrm{ONI}=+0.5$, Slemons et al., 2010, 2012; Grenier et al., 2013).

\section{Materials and Methods}

\subsection{Dissolved REE concentrations}

Seawater samples for the analysis of dissolved [REE] were collected at twelve stations. Seawater samples were collected using Niskin bottles and filtered through AcroPak500 filter cartridges (double membrane with $0.8 \mu \mathrm{m}$ and $0.45 \mu \mathrm{m}$ pore size) directly from the Niskin bottles or in the onboard laboratory and were acidified to $\mathrm{pH}=2$ using $6 \mathrm{~N} \mathrm{HCl}$ (optima quality, Fisher Chemical). At the ICBM of the University of Oldenburg, seawater REEs were purified and pre-concentrated using the automated seaFAST-pico system in offline mode (Elemental Scientific Inc., Nebraska, USA) and measured by isotope dilution (ID) inductively coupled plasma-mass spectrometry (ICP-MS) following the method described in Behrens et al. (2016). In more detail, seawater volumes of $\sim 11-55 \mathrm{~mL}(\mathrm{pH}=2)$ per sample were spiked with a multi-element spike containing all REEs (except the mono-isotopic elements) and passed together with a buffer solution $(\mathrm{pH}=6)$ and MilliQ water through the seaFAST column containing a REE-complexing resin (Nobias PA-1) that allows to wash out the seawater matrix. Total procedural onboard blanks of (onboard) MilliQ water and lab blanks 
125 were processed through the seaFAST column and subsequently spiked with a diluted multi126 element REE isotope spike for quantification.

127 Dissolved [REE] were analyzed using a Thermo Finnigan Element 2 ICP-MS coupled to an 128 autosampler (CETAC ASX-100) and a desolvation introduction system (CETAC Aridus 2)

129 (Behrens et al., 2016). Oxide formation rates were $0.01-0.03 \%$ (for $\mathrm{Ce}$ and $\mathrm{Ba}$ ) and no 130 corrections for oxide formation were therefore applied. The average instrumental blank of a $1312 \% \mathrm{HNO}_{3}$ solution was subtracted for each sample.

132 Rare earth element ratios and anomalies presented in this study are based on PAAS133 normalized (Taylor and McLennan, 1985) REE data (PAAS-normalization indicated by 134 subscript $\mathrm{N}$ in the following). The Eu anomaly is calculated as $\left[\mathrm{Eu} / \mathrm{Eu}^{*}\right] \mathrm{N}=[3 \times \mathrm{EuN} /(2 \times$ $135 \mathrm{SmN}+\mathrm{TbN})]($ Zhang et al., 2008).

136 The accuracy was checked with replicates of the GEOTRACES seawater standard SAFe $1373000 \mathrm{~m}$ and average [REE] agreed within the 2 SD confidence interval of the published 138 intercomparison study (Behrens et al., 2016) (Table S1a). Note that the REE data of Grenier 139 et al. (2013) and Pham et al. (2019), both carried out at LEGOS (Toulouse) and used for 140 comparison in this study (see section 5.2.), are consistent with our data, as this laboratory 141 successfully participated in the intercomparison study of Behrens et al. (2016). The external 142 standard deviation is derived from independently processed seawater replicates from a 143 sample from station 50 at $1001 \mathrm{~m}$ water depth (sample 50-2-8, n= 4) (Table S1b). If the 144 internal standard deviation of a sample was higher than this external value, the internal value 145 is reported. Average total procedural onboard $(n=8)$ and lab blanks $(n=14)$ were $\leq 1.9 \%$ for 146 all REEs, except for Ce $(4.9 \%, \mathrm{n}=20$, and $28 \%, \mathrm{n}=2)$ of the average sample concentration.

147 The standard deviation for $(\mathrm{Yb} / \mathrm{Er})_{\mathrm{N}}$ and $\left(\mathrm{Eu} / \mathrm{Eu}^{*}\right)_{\mathrm{N}}$ are \pm 0.03 and \pm 0.02 (1 SD), 148 respectively, and are based on sample replicates (sample 50-2-8, $\mathrm{n}=4$ ). 
150

151

152

153

154

155

156

157

158

159 are used (Alberty et al., 2019).

160 In addition, the large-scale currents context at the time of CASSIOPEE cruise is deduced

161 from the OSCAR surface current product (Bonjean and Largerloef, 2002). These near-surface

162 currents are representative of the 0-30 m layer, and are directly estimated from sea surface

163 height, near surface vector wind and sea surface temperature data. They are produced on a

$1641 / 3^{\circ}$ grid, 5 days temporal resolution, and are analyzed for the CASSIOPEE period in July-

165 August 2015.

166

167

168

169

170

171

172 m water depth) and near-surface (40-100 m water depth) layer. All our samples show positive

173 PAAS-normalized $\mathrm{Eu}$ anomalies of 1.13-1.27, with higher values found in the equatorial

174 zonal eastward SC compared to the westward SEC in the open ocean transect at $165^{\circ} \mathrm{E}$ (Fig. 
175 2a-c; Table S2). In addition, the near surface water is marked by a depletion in HREEs from 176 erbium (Er) to lutetium $(\mathrm{Lu})$ in PAAS-normalized REE patterns (Fig. S1) at all our stations, 177 this depletion being less pronounced in the equatorial zonal eastward SC (stations 69, 47, 29) 178 than in the westward SEC (stations 14, 19, 54, 57, 66) (Fig. S1a-c). This depletion is 179 illustrated using the normalized $\mathrm{Yb} / \mathrm{Er}$ ratio. In addition, we observe a small natural positive 180 Gd anomaly in all our seawater samples that typically occurs in PAAS-normalized REE

181

182 183

\subsection{Surface water $[R E E]$ in the study area (0-35 $\mathrm{m}$ water depth)}

Highest surface water [REE] (e.g., $\mathrm{Nd}=6.0-8.1 \mathrm{pmol} / \mathrm{kg}$ ) of all stations of this study are observed within the equatorial zonal eastward SC (stations 69, 47, 29) (Figs. 3a, c; S1a, b). In the extra-equatorial westward SEC, on the other hand, we find lowest surface water [REE] of all our stations $(\mathrm{Nd}=3.2-3.6 \mathrm{pmol} / \mathrm{kg}$, stations $14,19,54,57,66$, Fig. 3a, c), with a marked depletion of the HREEs expressed by low $(\mathrm{Yb} / \mathrm{Er})_{\mathrm{N}}$ ratios of $0.55-0.65$ compared to those of the $\mathrm{SC}\left((\mathrm{Yb} / \mathrm{Er})_{\mathrm{N}}=0.79-0.84\right)($ Figs. 3b; S1a, b).

Surface water sampled at the transition of the SEC and SC (stations 24 and 50) that flows into the Solomon Sea via the Solomon Strait (stations 60 and 63) shows slightly higher [REE] than within the SEC $(\mathrm{Nd}=4.1 \pm 0.3 \mathrm{pmol} / \mathrm{kg}, \mathrm{n}=7)($ Figs. 3a, c; S1a, b).

\subsection{Near-surface water [REE] in the study area (40-100 $\mathrm{m}$ water depth)}

In the equatorial zonal eastward SC, near-surface water $[\mathrm{REE}]([\mathrm{Nd}]=4.0-4.7 \mathrm{pmol} / \mathrm{kg})$ are slightly enriched relative to those of the extra-equatorial zonal westward SEC $([\mathrm{Nd}]=3.3-3.7$ $\mathrm{pmol} / \mathrm{kg}$ ), and decrease vertically from the surface to $100 \mathrm{~m}$ by up to $50 \%$ for $[\mathrm{Nd}]$ at station 69 (Figs. 3 c, d; S1b, c). Near-surface water [REE] within the SEC, on the other hand, are 
200 similar to those of the overlying surface water $(\mathrm{Nd}=3.2-3.6 \mathrm{pmol} / \mathrm{kg})($ Figs. $3 \mathrm{c}, \mathrm{d} ; \mathrm{S} 1 \mathrm{~b}, \mathrm{c})$.

201 In the Solomon Strait near New Britain, surface to near-surface water [REE] increase by $\sim 2.3$

$202 \mathrm{pmol} / \mathrm{kg} \mathrm{Nd}$ (station 63) (Figs. 3a, c, d; S1a-c).

203 In the following, we will compare our new REE data with published data in the study area 204 (Grenier et al., 2013; Pham et al., 2019; Behrens et al., 2018a). All the data considered here 205 lie within the surface mixed layer. However, the stations were sampled during different 206 seasons and years (EUC-Fe cruise, Aug.-Sept. 2006; PANDORA cruise, July-Aug. 2012; 207 SO223T cruise, Sept.-Oct. 2012), and thus reflect the hydrographic and geochemical data at 208 the particular time of sampling in this very dynamic area.

\section{Discussion}

\subsection{Rare earth element fluxes in the tropical West Pacific source area and surface and} near-surface zonal current system

\subsubsection{Surface water (0-35 $\mathrm{m}$ water depth)}

216 Surface water normalization of $[\mathrm{Nd}]$ and $[\mathrm{REE}]$ to those of upstream station GeoB17019 217 (Behrens et al., 2018a, black inverted triangle in Fig. 4a, b; normalized [Nd] referred to as $218 \mathrm{Nd}_{\text {norm }}$ ) indicates a more than 2-fold enrichment of REEs in the eastward SC (Fig. 5a, b). In 219 addition, we observe elevated positive $\left(\mathrm{Eu} / \mathrm{Eu}^{*}\right)_{\mathrm{N}}$ of surface water at the open ocean transect $220165^{\circ} \mathrm{E}\left(\left(\mathrm{Eu} / \mathrm{Eu}^{*}\right)_{\mathrm{N}}=1.23\right.$ and $1.26 \pm 0.02$, station 29 , Fig. 2a, b) and at nearby stations $221 \mathrm{GeoB} 17015$ to $-17\left(\left(\mathrm{Eu} / \mathrm{Eu}^{*}\right)_{\mathrm{N}}\right.$ up to 1.25 , Behrens et al., 2018a) compared to stations 14 and 22219 in the westward SEC $\left(\left(\mathrm{Eu} / \mathrm{Eu}^{*}\right)_{\mathrm{N}}=1.16-1.18 \pm 0.02\right.$, Fig. 2a, b). This indicates trace 223 element input from $\mathrm{PNG}$, with an imprint of the positive $\left(\mathrm{Eu} / \mathrm{Eu}^{*}\right)_{\mathrm{N}}$ signal from $\mathrm{PNG}$ 224 volcanic source rocks $\left(\mathrm{e} . \mathrm{g},\left(\mathrm{Eu} / \mathrm{Eu}^{*}\right)_{\mathrm{N}} \sim 1.4-1.5\right.$, Woodhead et al., 2010) onto seawater, and 
225 eastward transport to the equator via the western boundary current (NGCC) feeding the 226 equatorial eastward SC.

227 The combination of physical data with [REE] allows the quantification of trace element input $228\left(\mathrm{~F}_{\text {input }}=\mathrm{W} \times[\mathrm{Nd}]\right.$, with $\mathrm{W}$ as mass transport $(\mathrm{Sv})$ and $[\mathrm{Nd}]$ as dissolved $\mathrm{Nd}$ concentration $229(\mathrm{pmol} / \mathrm{kg}))$. In Vitiaz Strait, the mass transport in the 0-35 m layer varies from $-0.37 \mathrm{~Sv}$ to 1.1 $230 \mathrm{~Sv}$ in 2012-2014 (Alberty et al., 2019), depending on the season (stronger during June231 August, weaker during February-April, possibly reversing direction) and the El Niño 232 Southern Ocean Oscillation (ENSO) phase (stronger during El Niño, weaker during La Nina).

233 This transport was is in the upper range during the PANDORA cruise in July-Aug. 2012 234 (1.05 Sv, based on SADCP data), and during the CASSIOPEE cruise in July-Aug. 2015, 235 which took place at the onset of the strongest El Niño event of the early 21 st century 236 (Delpech et al., 2019). We estimate the surface water Nd flux in the Vitiaz Strait to be $\mathrm{F}_{\text {Vitiaz }}$ $237=22.3 \mathrm{t}(\mathrm{Nd}) / \mathrm{yr}$ during PANDORA and CASSIOPEE (using water transport of $1 \mathrm{~Sv}$ at $0-35 \mathrm{~m}$ 238 water depth at station 77 with $[\mathrm{Nd}]=4.9 \mathrm{pmol} / \mathrm{kg}$, Pham et al., 2019). The Vitiaz Strait 239 (station 77, Fig. 1a) is located upstream of PNG and the Sepik River.

240 For the Sepik River, we determine dissolved $\mathrm{Nd}$ input fluxes of $0.39 \mathrm{t}(\mathrm{Nd}) / \mathrm{yr}$ and 0.77 $241 \mathrm{t}(\mathrm{Nd}) / \mathrm{yr}$ using minimum discharge in Aug./Sept. $\left(2500 \mathrm{~m}^{3} / \mathrm{s}\right)$ and maximum discharge in 242 March/April $\left(5000 \mathrm{~m}^{3} / \mathrm{s}\right)$, respectively (Fig. 12a of Delcroix et al., 2014 and references 243 therein) and dissolved [Nd] of $34 \mathrm{pmol} / \mathrm{kg}$ at a salinity of 10 (Sholkovitz et al., 1999) and 244 assuming $86 \%$ removal of dissolved $\mathrm{Nd}$ in the estuary. Sepik River water [Nd] was sampled 245 in Aug. 1997 during the peak season of the SW monsoon period (June-Nov.) (Sholkovitz et 246 al., 1999), when surface water is transported from PNG to the equator (Lindstrom et al., 247 1987), and hence the imprint of an island weathering signature to equatorial surface water 248 was suggested (e.g., Milliman, 1995; Sholkovitz et al., 1999). Our estimated dissolved Sepik 249 River input fluxes of $0.39 \mathrm{t}(\mathrm{Nd}) / \mathrm{yr}$ and $0.77 \mathrm{t}(\mathrm{Nd}) / \mathrm{yr}$ are respectively $1.7 \%$ and $3.5 \%$ of the 
250

251 That is, the river input flux could account for a $0.1-0.2 \mathrm{pmol} / \mathrm{kg}$ enrichment in $\mathrm{Nd}$ or $3 \%$ and $6 \%$ of the observed seawater REE enrichment of $3.2 \mathrm{pmol} / \mathrm{kg} \mathrm{Nd}$ found in the equatorial 253 eastward SC downstream of the Sepik River at station 69. This implies a missing flux of $25412.0-12.6 \mathrm{t}(\mathrm{Nd}) / \mathrm{yr}$. In the following, we address the potential uncertainties of these estimates 255 (e.g., Sepik River discharge, Nd removal in the estuary, sampling location, temporal 256 variability in $\mathrm{Nd}$ distribution and water transport data).

257 Sholkovitz et al. (1999) mentioned that river water discharge data from PNG (i.e. the Sepik 258 River) was poorly documented, and at that time, they had to assume that half of the amount 259 of water that is discharged from all PNG rivers is discharged to the northern coast of PNG. 260 Thus, they used a total northern PNG river flow estimate that is 10 -fold higher than we used 261 in this study. In addition, Sholkovitz et al. (1999) assumed only 50\% of removal of dissolved $262 \mathrm{Nd}$ for the total northern PNG estuaries. In contrast, for the Sepik River estuary, we used $86 \%$ of Nd removal based on dissolved Sepik River water Nd data in the estuary reported in

264 Table 2 of Sholkovitz et al. (1999), who also mentioned that this removal rate is typical of 265 estuaries world wide (e.g., Goldstein and Jacobsen, 1988) and consistent with more recent 266 estimates of $71 \pm 16 \%$ (Rousseau et al., 2015). However, even if we consider the uncertainty 267 of $16 \%$, as suggested by Rousseau et al. (2015) for this estuarine removal, the river input flux 268 could account for a $0.2-0.3 \mathrm{pmol} / \mathrm{kg}$ enrichment in $\mathrm{Nd}$ or $6 \%$ and $9 \%$ of the observed 269 seawater REE enrichment of $3.2 \mathrm{pmol} / \mathrm{kg} \mathrm{Nd}$.

270 Other potential uncertainties of our estimation may be the sampling location and the temporal 271 variability in $\mathrm{Nd}$ distribution and water transport data. We therefore compare the dissolved 272 surface water [Nd] of $4.9 \mathrm{pmol} / \mathrm{kg}$ at station 77 (Vitiaz Strait, PANDORA, July 2012, Pham 273 et al., 2019) and equatorial surface water [Nd] (up to $8.1 \mathrm{pmol} / \mathrm{kg}$ ) at our station 69 274 (CASSIOPEE, Aug. 2015) to that of the equatorial nearby station GeoB17016 $([\mathrm{Nd}]=6.2$ 
$275 \mathrm{pmol} / \mathrm{kg}$, Sept. 2012, Behrens et al., 2018a). This station was sampled 1-2 months earlier than 276 the CASSIOPPEE and PANDORA stations, reflecting the transit time of surface water flow

277 from the Vitiaz Strait to the equator. The $[\mathrm{Nd}]$ difference reflects temporal variability in the 278 enrichment of $\mathrm{Nd}$ within equatorial surface. Nevertheless, the enrichment in dissolved $\mathrm{Nd}$ at 279 station GeoB17016, downstream of the river, of $1.3 \mathrm{pmol} / \mathrm{kg}$ still indicates an additional 280 significant source. Even if we would assume an open ocean surface water [Nd] of 3.5 $281 \mathrm{pmol} / \mathrm{kg}$ (station GeoB17019, Fig. 3c) at Vitiaz Strait, and water transport as low as $0.5 \mathrm{~Sv}$ 282 inside Vitiaz Strait to account for the fact that surface water at the equator during 283 CASSIOPEE was in Vitiaz Strait months earlier, the dissolved river input would only account 284 for an additional $7 \%$ input of $\mathrm{Nd}$ to the flux of $8.0 \mathrm{t}(\mathrm{Nd}) / \mathrm{yr}$ through Vitiaz Strait. This finding 285 indicates that there is a significant source of REE input from PNG in addition to the river 286 input. In the following, we discuss potential sources such as sediments and volcanic rocks 287 from PNG, Sepik river particles, submarine groundwater discharge (SGD), benthic flux from 288 pore waters, volcanic ash deposition, or admixture of northern hemisphere derived surface 289 water.

290 Surface water derived from the northern hemisphere (e.g., station GeoB17014, $\sim 6^{\circ} \mathrm{N}, 5-22 \mathrm{~m}$ 291 water depth: $([\mathrm{Nd}]=4.5 \pm 0.3 \mathrm{pmol} / \mathrm{kg}, \mathrm{n}=2$, Fig. S3a) has lower dissolved $[\mathrm{Nd}]$ than that of 292 our equatorial stations, and is thus not a potential source.

293 It has been shown that volcanic dust input from active volcanoes is a REE source in this 294 region (e.g., Grenier et al., 2013; Pham et al., 2019). If volcanic dust input through ash 295 deposition and dissolution would play a significant role in surface water REE enrichments of 296 the zonal current system, we would also expect to find this enrichment signal in surface water 297 flowing within the westward SEC. Yet, in contrast to the enriched equatorial eastward SC, 298 surface water [REE] in the zonal westward SEC (stations 14, 19, 54, 57, 66) are similar to 299 open ocean concentrations indicating lateral transport of preformed [REE] $\left(\mathrm{Nd}_{\text {norm }} \sim 1\right.$, Figs. 
300

301

302

303

304

305

306

307

308

309

310

311

312

313

314

315

316

317

318

319

320

321

322

323

324

$4 a, b ; 5 a, b)$. This excludes the possibility of volcanic dust dissolution in the zonal current system as source for the elevated [REE]. In addition, low $(\mathrm{Yb} / \mathrm{Er})_{\mathrm{N}}$ ratios of $0.55-0.69$ in surface water within the SEC (Behrens et al., 2018a; this study) suggest preferential removal of the heaviest REEs from seawater along the transport path (Figs. 3b, 6a, b), likely due to adsorption of the heaviest REEs onto bacteria cell walls (e.g., Takahashi et al., 2005) and/or biogenic silica uptake (e.g., Akagi, 2013; Grenier et al., 2018). In contrast, surface water within the SC show slightly higher $(\mathrm{Yb} / \mathrm{Er})_{\mathrm{N}}$ ratios of $0.79-0.84$ suggesting recent input from PNG (Fig. 6b, c).

Moreover, our seawater-normalized REE patterns within the eastward SC are marked by an MREE enrichment (Fig. 5). This MREE enrichment is also observed for Sepik River water and sediment (Sholkovitz et al., 1999), PNG sediments and volcanic rocks (Grenier et al., 2013). In addition, several studies (e.g., Abbott et al., 2015; Johannesson et al., 2017) pointed out the importance of benthic REE flux from pore waters and SGD in the Pacific, and found MREE-enriched pore waters (e.g., Haley et al., 2004; Abbott et al., 2019) and SGD (Kim and Kim, 2011, 2014). However, to our knowledge, there is no SGD and pore water REE data reported from PNG. Here, we cannot differentiate between these particulate sources nor SGD or pore water input from PNG. The importance of PNG margin sediments as major source of TE input has also previously been suggested in several other studies on REE and Fe (Grenier et al., 2013; Labatut et al., 2014; Behrens et al., 2018a). Here we show for the first time, that the dissolved river input can only account for an additional $2-3.5 \%$ input of $\mathrm{Nd}$ to the annual flux of Nd through Vitiaz Strait, and that both fluxes cannot explain the REE enrichment in the eastward SC. This missing flux of 12.0-12.6 $\mathrm{t}(\mathrm{Nd}) / \mathrm{yr}$ originates from the PNG shelf.

At the transition of the zonal SEC and SC (stations 24 and 50), less enriched [REE] than in the $\mathrm{SC}$ (e.g., maximum $\mathrm{Nd}_{\text {norm }}$ of 1.28 , Table $\mathrm{S} 3$ ) suggest mixing of $\mathrm{SC}$ and $\mathrm{SEC}$ source waters (Figs. 4a, b; $5 \mathrm{a}, \mathrm{b}$ ). This is further supported by plots of salinity vs. [Nd] and [Yb], in 
325 which the surface water data from stations 24 and 50 fall on a mixing line between high

326 salinity, low [REE] extra-equatorial surface water of the SEC and low salinity, high [REE]

327 equatorial water of the SC (Fig. 6a-c). This mixed surface water (together with the no 328 enriched, preformed [REE] water of the zonal SEC) flows into the Solomon Sea via the

329 Solomon Strait $\left(\mathrm{Nd}_{\text {norm }}\right.$ up to 1.2, stations 60, 63) (Fig. 4a, b; 6a; Table S3).

330 Overall, our data indicate (1) elemental input largely from PNG margin sediments and 331 transport via the NGCC to and within the equatorial eastward flowing SC, (2) westward 332 lateral transport of preformed [REE] within the extra-equatorial SEC, and (3) lateral mixing 333 of Eastern and Western Pacific source waters in the transition between the eastward and 334 westward currents (SC, SEC) at $\sim 3^{\circ} \mathrm{S}$. Our findings provide clear evidence for a discrete 335 origin of the REE-enriched SC in the Tropical Western Pacific (more than 2-fold enriched $336[\mathrm{REE}], \mathrm{Nd}_{\text {norm }}$ up to $2.3,(\mathrm{Yb} / \mathrm{Er})_{\mathrm{N}}$ ratios up to 0.84$)$ compared to no enriched waters flowing 337 within the zonal westward SEC (preformed [REE], $\mathrm{Nd}_{\text {norm }} \sim 1,(\mathrm{Yb} / \mathrm{Er})_{\mathrm{N}}$ ratios as low as 0.55 ) 338 and mixing at the transition of both currents (stations 24 and $50, \mathrm{Nd}_{\text {norm }}$ up to 1.2). Moreover, 339 our results are in line with the surface water distribution of total dissolvable [Fe] in our study 340 area, that show highest values within the NGCC near the PNG margin ([Fe] up to $17 \mathrm{nM})$ and 341 within the equatorial zonal eastward SC ([Fe] up to $0.9 \mathrm{nM}$ ) (Slemons et al., 2010, 2012) 342 relative to those of the Coral and Solomon Seas that are fed by the westward SEC ([Fe] $=$ $343 \quad 0.05-0.07 \mathrm{nM})$ (Obata et al., 2008) (Fig. 3e).

345 5.1.2. Near-surface water (40-100 $\mathrm{m}$ water depth)

346 Near-surface water normalization of [Nd] and [REE] to those of upstream station GeoB17019 347 (Behrens et al., 2018a, black inverted triangle in Fig. 4c) indicates a slight enrichment of 348 REEs in the $\mathrm{SC}\left(\mathrm{Nd}_{\text {norm }}=1.2-1.4\right)$ (Fig. 5c). In combination with an elevated positive $349\left(\mathrm{Eu} / \mathrm{Eu}^{*}\right)_{\mathrm{N}}$ of near-surface water at the open ocean transect $165^{\circ} \mathrm{E}\left(\left(\mathrm{Eu} / \mathrm{Eu}^{*}\right)_{\mathrm{N}}=1.21 \pm 0.02\right.$, 
350

351

352

353

354

355

356

357

358

359

360

361

362

363

364

365

366

367

368

369

370

371

372

373

374

station 29, Fig. 2c) and at nearby stations GeoB17015 to $-17\left(\left(\mathrm{Eu} / \mathrm{Eu}^{*}\right)_{\mathrm{N}}\right.$ up to 1.23 , Behrens et al., 2018a) compared to stations 14 and 19 in the westward SEC $\left(\left(\mathrm{Eu} / \mathrm{Eu}^{*}\right)_{\mathrm{N}}=1.14 \pm 0.02\right.$, Fig. 2c), this indicates trace element input from PNG and eastward transport to the equator via NGCC feeding the equatorial eastward SC. However, this near-surface water enrichment of REEs in the $\mathrm{SC}$ is lower than that of the overlying surface water $\left(\mathrm{Nd}_{\text {norm }}=1.7-2.3\right)$ (Figs. 4a-c; 5a-c), indicating a vertical decrease in [REE] in the SC towards 40-100 m water depth (e.g., $50 \%$ for $[\mathrm{Nd}]$ at station 69 , Fig. 3 c, d). This rapid [REE] decline with depth within the SC that cannot be related to the local bathymetry (all stations are deeper than $1400 \mathrm{~m}$ ), is also observed for total dissolvable [Fe] within the NGCC near the PNG margin, decreasing by $43 \%$ from the surface to near-surface (Slemons et al., 2010, 2012) (Fig. 3e, f). Given this vertical decline in surface to near-surface $[\mathrm{Fe}]$ near the PNG margin, and seeing that PNG is the source of the surface and near-surface trace element input found within the SC, we suggest that input to the surface layer near PNG explains this rapid decline with depth in [REE] (and probably [Fe]) within the surface mixed layer. In the westward SEC, on the other hand, similar surface and near-surface water [REE] (Fig. 3c, d), and no enriched REE patterns $\left(\mathrm{Nd}_{\text {norm }} \sim 1\right)$ (Figs. $\left.4 \mathrm{c} ; 5 \mathrm{c}\right)$, indicate westward lateral transport of preformed surface and near-surface water [REE] within the extra-equatorial SEC (stations, 14, 19, 54, 57, 66), except for the inflow into the Solomon Strait (station 63). Here, the vertical increase in surface to near-surface water [REE] (by $\sim 2.3 \mathrm{pmol} / \mathrm{kg}[\mathrm{Nd}]$ towards $51 \mathrm{~m}$ water depth), with a REE enrichment over upstream water $(\mathrm{SEC})\left(\mathrm{Nd}_{\text {normalized }}=1.93\right)$, points to local REE input from the New Britain and New Ireland shelves (Figs. 4a-c; 5a-c). This is supported by physical observations in the Solomon Strait. In the western part of the Solomon Strait at $51 \mathrm{~m}$ water depth (station 63), current velocities are almost zero (or slightly positive indicating outflow, Fig. S2) suggesting that during the station, with the strong tide, the near-surface water gets probably enriched from both shelves inside and outside of the Solomon Sea. 
376 5.2. Temporal and spatial variability in surface and near-surface water REE

\section{7 distributions in the study area}

378 The CASSIOPEE cruise took place at the onset of the strongest El Niño event of the early 37921 st century (ONI of +1.5 to +1.8 ) and coincides with strong westerly wind events during the 380 cruise (Delpech et al., 2019). That is, trace element input from the Tropical Western Pacific 381 volcanic islands (Grenier et al., 2013; this study) is influenced by island weathering being 382 related to precipitation during the SW monsoon period and the entrainment of this signal to 383 equatorial surface water (e.g., Milliman, 1995; Sholkovitz et al., 1999, see section 5.1.1.), that 384 is expected to be influenced by these intraseasonal and interannual climate fluctuations, with 385 stronger eastward surface currents during an El Niño event.

386 In order to evaluate the temporal variability in surface water REE input in the eastward SC, 387 we compare the surface water [Nd] during a strong El Niño year (station 69, CASSIOPEE 388 cruise, July-Aug., 2015), with strong eastward surface currents near the equator, with that 389 from a weak El Niño year (stations EUC-Fe 25 and 26, ONI $=+0.5$, EUC-Fe cruise, Aug.390 Sept. 2006, Slemons et al., 2010, 2012; Grenier et al., 2013), with weaker eastward currents 391 (Fig. S3a-c). Surface water $[\mathrm{Nd}]$ at stations EUC-Fe 26, $25([\mathrm{Nd}]=6.6 \mathrm{pmol} / \mathrm{kg}, 6.1 \mathrm{pmol} / \mathrm{kg})$ 392 and station $69([\mathrm{Nd}]=8.1 \mathrm{pmol} / \mathrm{kg})$ vary in $[\mathrm{Nd}]$ by $1.5-2 \mathrm{pmol} / \mathrm{kg}$ (Fig. S3a). In contrast, 393 northern hemisphere derived surface water (station GeoB17014, $[\mathrm{Nd}]=4.6 \mathrm{pmol} / \mathrm{kg}$, Behrens 394 et al., 2018a) is marked by lower [Nd] similar to that in the Vitiaz Strait (station 77 , $[\mathrm{Nd}]=$ $3954.9 \mathrm{pmol} / \mathrm{kg}$, Pham et al., 2019) (Fig. S3a). Thus, this difference in the [Nd] for the 396 CASSIOPEE and EUC-Fe cruises likely indicates temporal variability of input and transport 397 in the PNG source area and the equatorial region, likely related to changes in ENSO 398 conditions. However, we are aware that nearby station EUC-Fe 25 is not sampled at exactly 
399 the same location as station 69 (separated by $1^{\circ} \mathrm{S}, 3.5^{\circ} \mathrm{E}$ ), and that we thus also observe a 400 strong spatial variability in REE distribution.

401 In the Solomon Sea and its Straits, surface and near-surface waters of this study and the 402 previous study of Pham et al. (2019) indicate spatial variability in REE distributions with $403[\mathrm{Nd}]$ ranging from $3.3 \mathrm{pmol} / \mathrm{kg}$ up to $8.2 \mathrm{pmol} / \mathrm{kg}$ due to varying local continental inputs such 404 as from the volcanic island margins and active volcanoes of New Britain and New Ireland $405\left([\mathrm{Nd}]=5.2-8.2 \mathrm{pmol} / \mathrm{kg}, \mathrm{Nd}_{\text {norm }}=1.5-2.4\right.$, stations 63 , this study, St. 36, St. 53, St. 57, St. 60, 406 Pham et al., 2019) (Figs. 3c, e; 4b, c). In contrast, surface and near-surface waters of the 407 westward SEC at all our stations (stations 14, 19, 54, 57, 66) and published stations (St. 10, 408 St. 13, St. 43, GeoB17018-19, Behrens et al., 2018a; Pham et al., 2019) lack a significant 409 variability in REE distributions, indicating no input and thus lateral transport of invariant 410 preformed $[\mathrm{REE}]$ from the East Pacific $\left([\mathrm{Nd}]=3.5 \pm 0.2 \mathrm{pmol} / \mathrm{kg}, \mathrm{n}=22, \mathrm{Nd}_{\mathrm{norm}} \sim 1\right)($ Fig. $4113 a, c, d ; 4 a-c)$.

\section{Conclusions}

414 Our study presents dissolved surface to near-surface water REE concentrations ([REE]) (0$415100 \mathrm{~m}$ water depth) at 10 stations in the zonal current system of the Tropical Western Pacific 416 and two stations in the Solomon Strait, one of the areas where water enters the Solomon Sea.

417 More than 2-fold enriched surface water [REE] in the equatorial zonal eastward surface 418 current (SC) compared to the zonal westward South Equatorial Current (SEC) indicate 419 significant elemental input. Flux calculations from combined geochemical data and ADCP 420 current velocities indicate that this surface water input is largely derived from the basaltic 421 Papua New Guinea margin sediments and/or Sepik River particles. Dissolved Sepik River 422 input only accounts for an additional 2-3.5\% input of $\mathrm{Nd}$ to the annual flux of $\mathrm{Nd}$ through 423 Vitiaz Strait, which cannot explain the REE enrichment in the eastward SC. 
424 We find temporal and spatial variability of surface water $\mathrm{Nd}$ input and transport in the PNG

425 source area and the equatorial region within the eastward $\mathrm{SC}$, with up to $2 \mathrm{pmol} / \mathrm{kg}$ higher

$426[\mathrm{Nd}]$ at the onset of the strongest El Niño event of the early 21 st century (this study, July-

427 Aug., 2015) compared to a weak El Niño year (Aug.-Sept. 2006, EUC-Fe cruise).

428 In the Solomon Sea and its Strait, spatial variability in surface and near-surface water [REE]

429 (this study and Pham et al., 2019) is related to varying local coastal inputs, particularly near

430 New Ireland and New Britain. In the westward SEC, on the other hand, the lack of REE input

431 and significant variability in REE distribution of this study and published data indicates

432 lateral transport of preformed seawater [REE] into the study area.

433 Our findings provide clear evidence for a discrete origin of the REE-enriched SC in the

434 Tropical Western Pacific (more than 2-fold enriched [REE], $\mathrm{Nd}_{\text {norm }}$ up to 2.3, $(\mathrm{Yb} / \mathrm{Er})_{\mathrm{N}}$ ratios

435 up to 0.84) compared to no enriched waters flowing within the zonal westward SEC

436 (preformed [REE], $\mathrm{Nd}_{\text {norm }} \sim 1,(\mathrm{Yb} / \mathrm{Er})_{\mathrm{N}}$ ratios as low as 0.55$)$ and mixing at the transition of

437 both currents (stations 24 and $50, \mathrm{Nd}_{\text {norm }}$ up to 1.2).

438

439 7. Acknowledgements

440 We thank the scientific party, captain and crew of R/V L'Atalante cruise CASSIOPEE. We 441 further thank $M$. Schulz for her help in the lab. The CASSIOPEE cruise 442 (https://doi.org/10.17600/15001200) was supported by the French national programme 443 LEFE/INSU, within the project ZEBRE. Financial support for this study came from the 444 Deutsche Forschungsgemeinschaft (DFG, German Research Foundation) - 396302194 445 through grant BE6184/2-1 to M. Behrens, the Institute for Chemistry and Biology of the 446 Marine Environment (ICBM) and the Max Planck Institute for Marine Microbiology, 447 Bremen. 


\section{References}

Abbott A. N., Haley B., McManus J. and Reimers C. (2015) The sedimentary source of dissolved rare earth elements to the ocean. Geochim. Cosmochim. Acta 154, 186-200.

Akagi T. (2013) Rare earth element (REE)-silicic acid complexes in seawater to explain the incorporation of REEs in opal and the "leftover" REEs in surface water: New interpretation of dissolved REE distribution profiles. Geochim. Cosmochim. Acta 113, 174-192.

Alberty M., Sprintall J., MacKinnon J., Germineaud C., Cravatte S. and Ganachaud A. (2019) Moored observations of transport in the Solomon Sea. J. Geophys. Res. Oceans 124, 8166-8192.

Behrens M. K., Muratli J., Pradoux C., Wu Y., Böning P., Brumsack H.-J., Goldstein S. L., Haley B., Jeandel C., Paffrath R., Pena L. D., Schnetger B. and Pahnke K. (2016) Rapid and precise analysis of rare earth elements in small volumes of seawater - Method and intercomparison. Mar. Chem. 186, 110-120.

Behrens M. K., Pahnke K., Paffrath R., Schnetger B. and Brumsack H.-J. (2018a). Rare earth element distributions in the West Pacific: trace element sources and conservative vs. non-conservative behavior. Earth Planet. Sci. Lett. 486, 166-177.

Behrens M. K., Pahnke K., Schnetger B. and Brumsack H.-J. (2018b) Sources and processes affecting the distribution of dissolved $\mathrm{Nd}$ isotopes and concentrations in the West Pacific. Geochim. Cosmochim. Acta 222, 508-534.

Bonjean F. and Lagerloef G.S.E. (2002) Diagnostic model and analysis of the surface currents in the tropical Pacific ocean. J. Phys. Oceanogr. 32, 2938-2954.

Byrne R. H. and Kim K.-H. (1990) Rare earth element scavenging in seawater. Geochim. Cosmochim. Acta 54, 2645-2656. 
473 Cravatte S., Ganachaud A., Duong Q.-P., Kessler W. S., Eldin G. and Dutrieux P. (2011) 474 Observed circulation in the Solomon Sea from SADCP data. Prog. Oceanogr. 88, 116$475 \quad 130$

476 de Baar H. J. W., Bruland K. W., Schijf J., van Heuven S. M. A. C. and Behrens M. K. 477 (2018) Low Cerium among the dissolved rare earth elements in the central North Pacific 478 Ocean. Geochim. Cosmochim. Acta 236, 5-40.

479 Delcroix T., Radenac M. H., Cravatte S., Alory G., Gourdeau L., Léger F., Singh A. and 480 Varillon D. (2014) Sea surface temperature and salinity seasonal changes in the western $481 \quad$ Solomon and Bismarck Seas. J. Geophys. Res. 119, 2642-2657.

482 Delpech A., Cravatte S., Marin F., Morel Y., Gronchi E. and Kestenare E. (2019) Observed 483 484 tracer fields structuration by mid-depth zonal jets in the tropical Pacific. J. Phys.

485 486 487 488 489 490 491 492 493 494 495 496

497 Grenier M., Jeandel C., Lacan F., Vance D., Venchiarutti C., Cros A. and Cravatte S. (2013) Oceanogr., accepted. DOI:10.1175/JPO-D-19-0132.1

Elderfield H. and Greaves M. J. (1982) The rare earth elements in seawater. Nature 296, 214219.

Fine R. A., Lukas R., Bingham F. M., Warner M. J. and Gammon R. H. (1994) The western equatorial Pacific - a water mass crossroads. J. Geophys. Res. Oceans 99, 25063-25080.

Ganachaud A., Cravatte S., Sprintall J., Germineaud C., Alberty M., Jeandel C., Eldin G., Metzl N., Bonnet S., Benavides M., Heimburger L.-E., Lefèvre J., Michael S., Resing J., Quéroué F., Sarthou G., Rodier M., Berthelot H., Baurand F., Grelet J., Hasegawa T., Kessler W., Kilepak M., Lacan F., Privat E., Send U., Van Beek P., Souhaut M. and Sonke J. E. (2017) The Solomon Sea: its circulation, chemistry, geochemistry and biology explored during two oceanographic cruises. Elem. Sci. Anth. 5(0), 33.

Goldstein S. J. and Jacobsen S. B. (1988). REE in the Great Whale River estuary, northwest Quebec. Earth Planet. Sci. Lett. 88, 241-252. 

From the subtropics to the central equatorial Pacific Ocean: Neodymium isotopic composition and rare earth element concentration variations. J. Geophys. Res. Oceans $118,592-618$.

Grenier M., Jeandel C. and Cravatte S. (2014) From the subtropics to the equator in the Southwest Pacific: Continental material fluxes quantified using neodymium data along modeled thermocline water pathways. Geophys. Res. Oceans 119, 3948-3966.

Grenier M., Garcia-Solsona E., Lemaitre N., Trull T. W., Bouvier V., Nonnotte P., van Beek P., Souhaut M., Lacan F., Jeandel C. (2018) Differentiating Lithogenic Supplies, Water Mass Transport, and Biological Processes On and Off the Kerguelen Plateau Using Rare Earth Element Concentrations and Neodymium Isotopic Compositions. Front. Mar. Sci., $5: 426$

Haley B. A., Klinkhammer G. P. and McManus J. (2004) Rare earth elements in pore waters of marine sediments. Geochim. Cosmochim. Acta 68, 1265-1279.

Hristova H. G. and Kessler W. S. (2012) Surface circulation in the Solomon Sea derived from Lagrangian drifter observations. J. Phys. Oceanogr. 42, 448-458.

Johannesson K. H., Palmore C. D., Fackrell J., Prouty N. G., Swarzenski P. W., Chevis D. A., Telfeyan K., White C. D. and Burdige D. J. (2017). Rare earth element behavior during groundwater-seawater mixing along the Kona Coast of Hawaii. Geochim. Cosmochim. Acta 198, 229-258.

Kim I. and Kim G. (2011) Large fluxes of rare earth elements through submarine groundwater discharge (SGD) from a volcanic island, Jeju, Korea. Mar. Chem. 127, $12-$ 19.

Kim I. and Kim G. (2014) Submarine groundwater discharge as a main source of rare earth elements in coastal waters. Mar. Chem. 160, 11-17. 
Labatut M., Lacan F., Pradoux C., Chmeleff J., Radic A., Murray J. W., Poitrasson F., Johansen A. M. and Thil F. (2014) Iron sources and dissolved-particulate interactions in the seawater of the Western Equatorial Pacific, iron isotope perspectives. Glob. Biogeochem. Cycles 28, 1044-1065.

Lacan F. and Jeandel C. (2001) Tracing Papua New Guinea imprint on the central equatorial Pacific Ocean using neodymium isotopic compositions and rare earth element patterns. Earth Planet. Sci. Lett. 186, 497-512.

Lacan F. and Jeandel C. (2005) Neodymium isotopes as a new tool for quantifying exchange fluxes at the continent-ocean interface. Earth Planet. Sci. Lett. 232, 245-257.

Lindstrom E., Lukas R., Fine R., Godfrey S., Meyers G., Tsuchiya M. (1987) The western equatorial Pacific Ocean circulation study. Nature 330, 533-537.

Milliman J. D. (1995) Sediment discharge to the ocean from mountainous rivers: the New Guinea example. Geo-Mar. Lett. 15, 127-133.

Molina-Kescher M., Hathorne E.C., Osborne A.H., Behrens M.K., Kölling M., Pahnke K. and Frank M. (2018) The Influence of Basaltic Islands on the Oceanic REE Distribution: A Case Study From the Tropical South Pacific. Front. Mar. Sci., 5:50.

Obata H., Shitashima K., Isshiki K. and Nakayama E. (2008) Iron, Manganese and Aluminium in upper waters of the Western South Pacific Ocean and its adjacent seas. $J$. Oceanogr. 64, 233-245.

Pham V. Q., Grenier M., Cravatte S., Michael S., Jacquet S., Belhadj M., Nachez Y., Germineaud C. and Jeandel C. (2019) Dissolved rare earth elements distribution in the Solomon Sea. Chem. Geol. 524, 11-36.

Radenac M.-H., Léger F., Messié M., Dutrieux P., Menkes C. and Eldin G. (2016) Winddriven changes of surface current, temperature, and chlorophyll observed by satellites north of New Guinea. J. Geophys. Res. Oceans 121, 2231- 2252. 
Radic A., Lacan F. and Murray J. W. (2011) Iron isotopes in the seawater of the equatorial Pacific Ocean: New constraints for the oceanic iron cycle. Earth Planet. Sci. Lett. 306, 110.

Reverdin G., Frankignoul C., Kestenare E. and McPhaden M. J. (1994) Seasonal variability in the surface currents of the equatorial Pacific. J. Geophys. Res.: Oceans 99, 2032320344.

Rousseau T. C. C., Sonke J. E., Chmeleff J., Van Beek P., Souhaut M., Boaventura G., Seyler P. and Jeandel C. (2015) Rapid neodymium release to marine waters from lithogenic sediments in the Amazon estuary. Nat. Commun. 6, 7592.

Schlitzer R. (2016) Ocean Data View, http://odv.awi.de.

Sholkovitz E. R., Elderfield H., Szymczak R. and Casey K. (1999) Island weathering: river sources of rare earth elements to the Western Pacific Ocean. Mar. Chem. 68, 39-57.

Slemons L.O., Murray J.W., Resing J., Paul B. and Dutrieux P. (2010) Western Pacific coastal sources of iron, manganese and aluminum to the equatorial undercurrent. Global Biogeochem. Cycles 24, GB3024.

Slemons L., Paul B., Resing J. and Murray J. W. (2012) Particulate iron, aluminum, and manganese in the Pacific equatorial undercurrent and low latitude western boundary current sources. Mar. Chem. 142-144, 54-67.

Takahashi Y., Chatellier X., Hattori K. H., Kato K. and Fortin D. (2005) Adsorption of rare earth elements onto bacterial cell walls and its implication for REE sorption onto natural microbial mats. Chem. Geol. 219, 53-67.

Taylor S. R. and McLennan S. M. (1985) The continental crust, its composition and evolution: An examination of the geochemical record preserved in sedimentary rocks. Blackwell, Oxford. 
571 Woodhead J. D., Hergt J. M., Sandiford M. and Johnson W. (2010) The big crunch: physical 572 and chemical expressions of arc/continent collision in the western Bismarck Arc. $J$. 573 Volcanol. Geotherm. Res. 190, 11-24.

574 Zhang Y., Lacan F. and Jeandel C. (2008) Dissolved rare earth elements tracing lithogenic 575 inputs over the Kerguelen Plateau (Southern Ocean). Deep Sea Res. II 55, 638-652. 
(Pigurierface (0-35 m water depth) and near-surface water (40-100 m water depth) Click here to download Figure: Figure 1.pdf
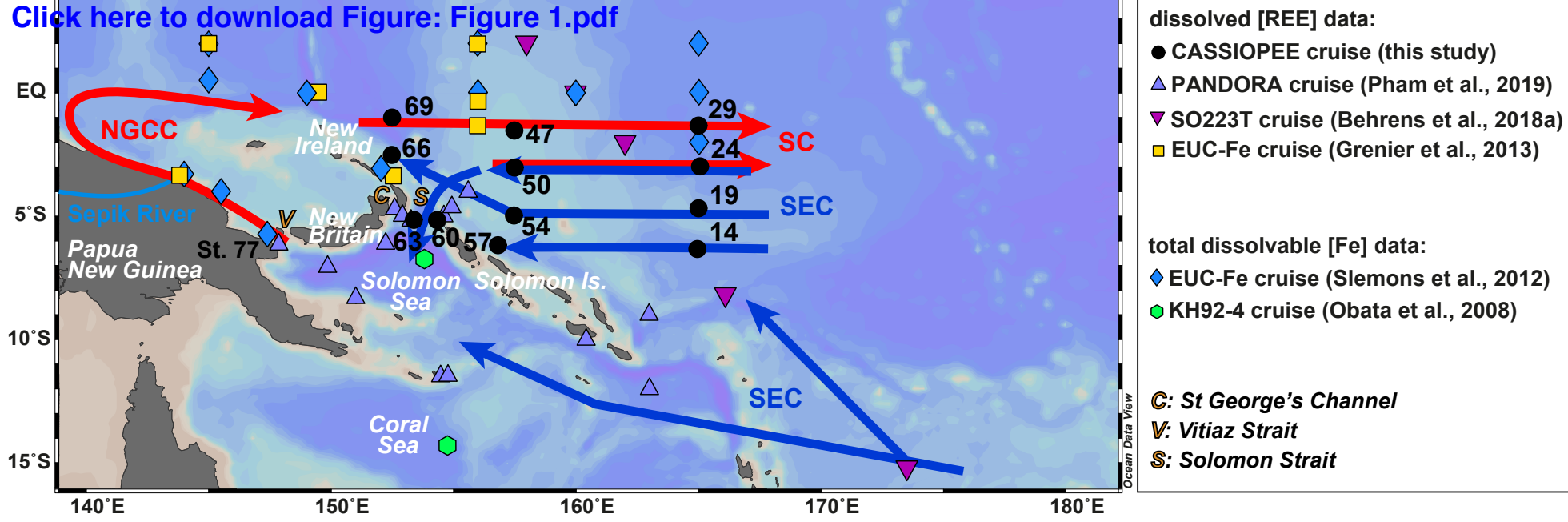

(b) Surface current velocities (10-35 m water depth) from OSCAR product (in color) in August 2015 and S-ADCP data from CASSIOPEE cruise (black bold arrows)

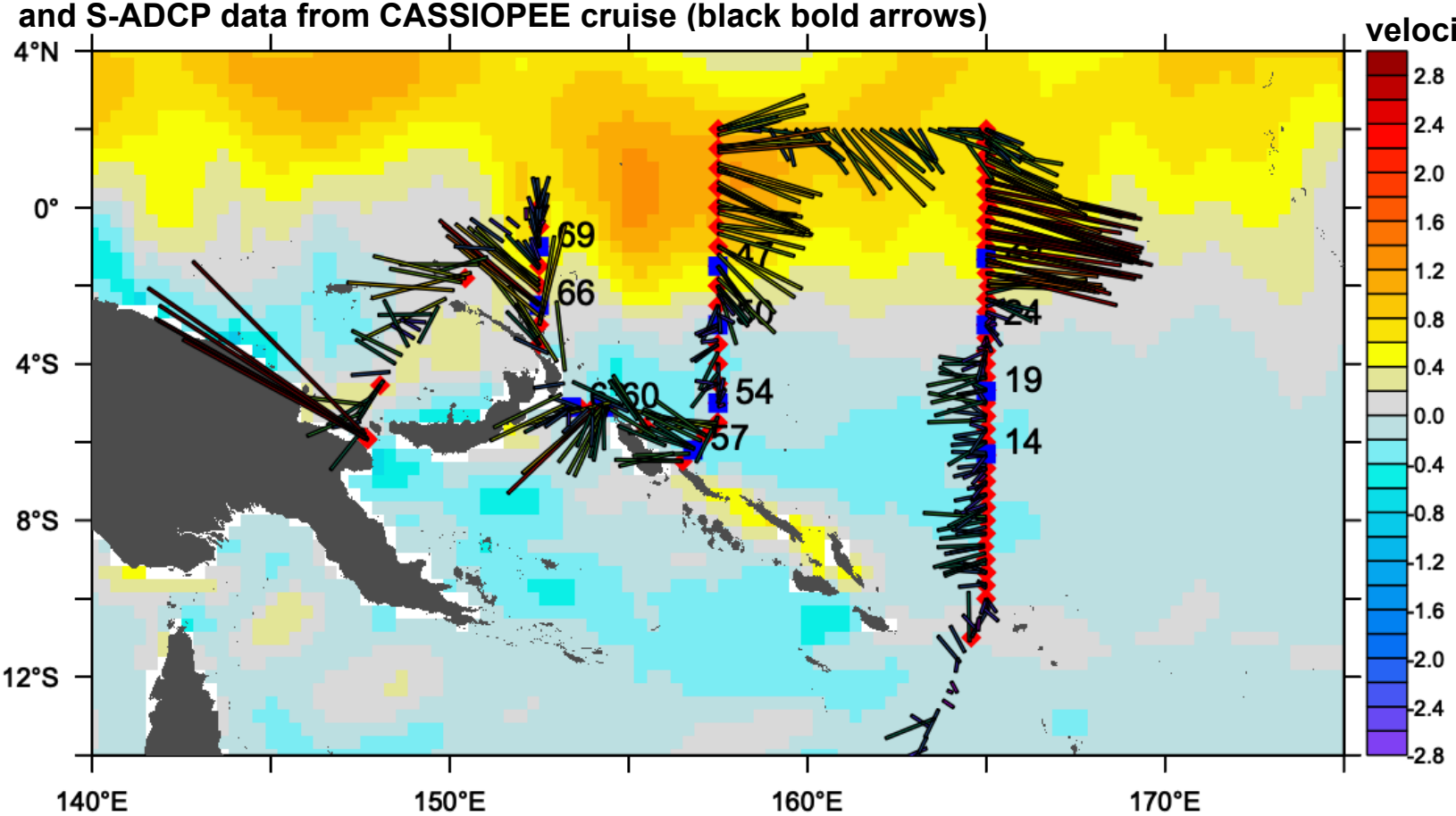

S-ADCP $-50 \mathrm{~cm} / \mathrm{s}$

(c) Near-surface current velocities (40-100 m water depth) from OSCAR product (in color) in August 2015 and S-ADCP data from CASSIOPEE cruise (black bold arrows)

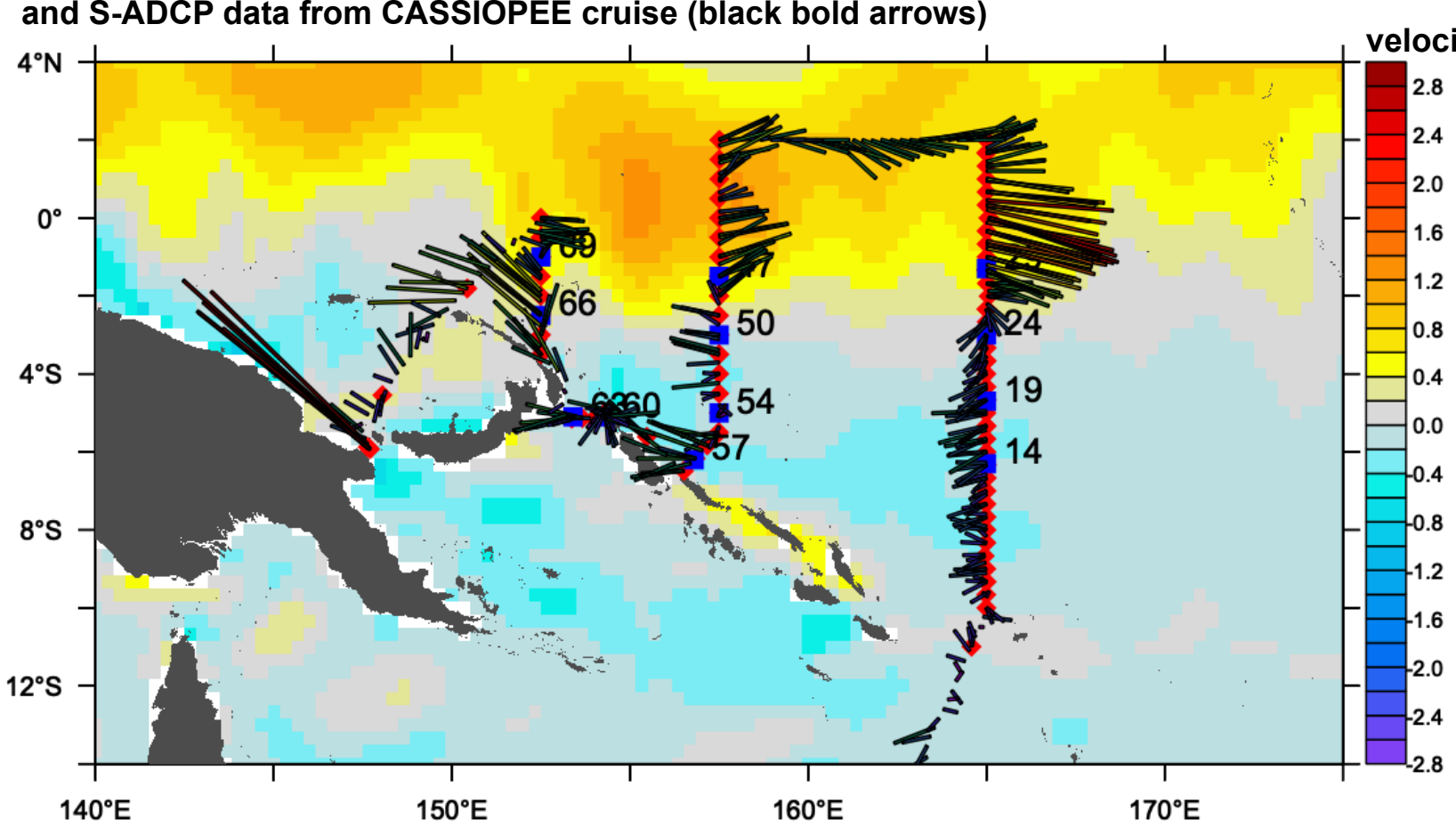


(qiSuffecewater (0-9 m water depth)

$\left(\mathrm{Eu} / \mathrm{Eu}^{*}\right)_{\mathrm{N}}$

Elick here to dow ${ }^{6} h$ load Figure: Figure 2. padf

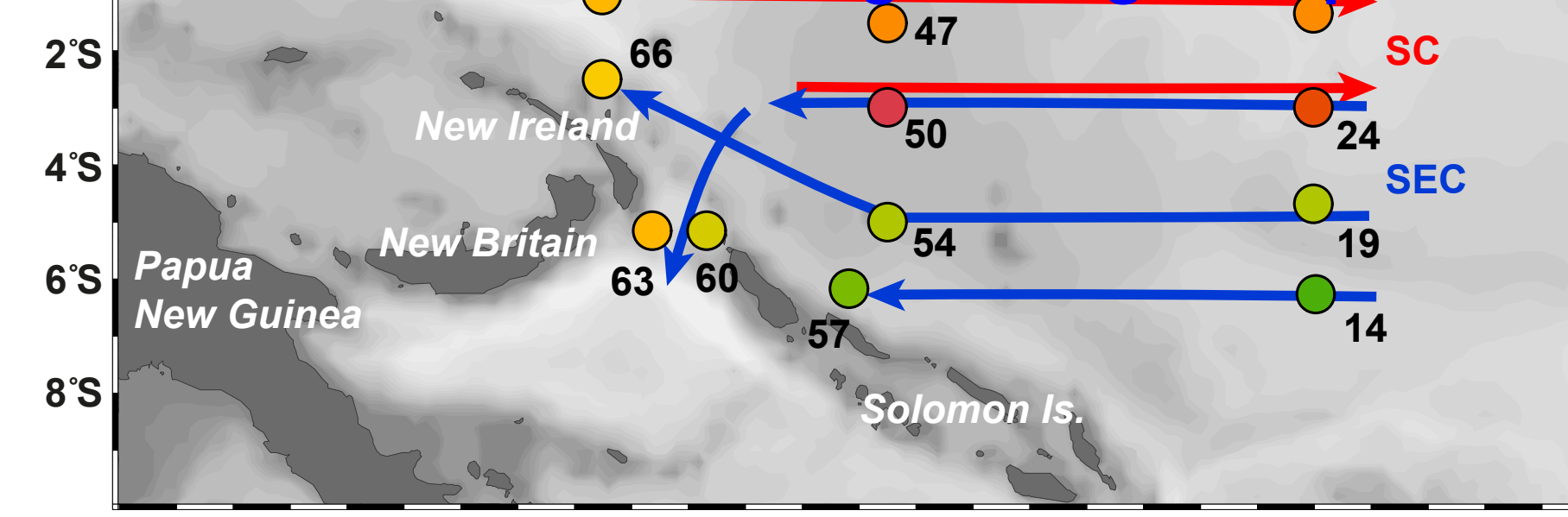

(b) Surface water (10-35 m water depth)

$\left(\mathrm{Eu} / \mathrm{Eu}^{*}\right)_{\mathrm{N}}$

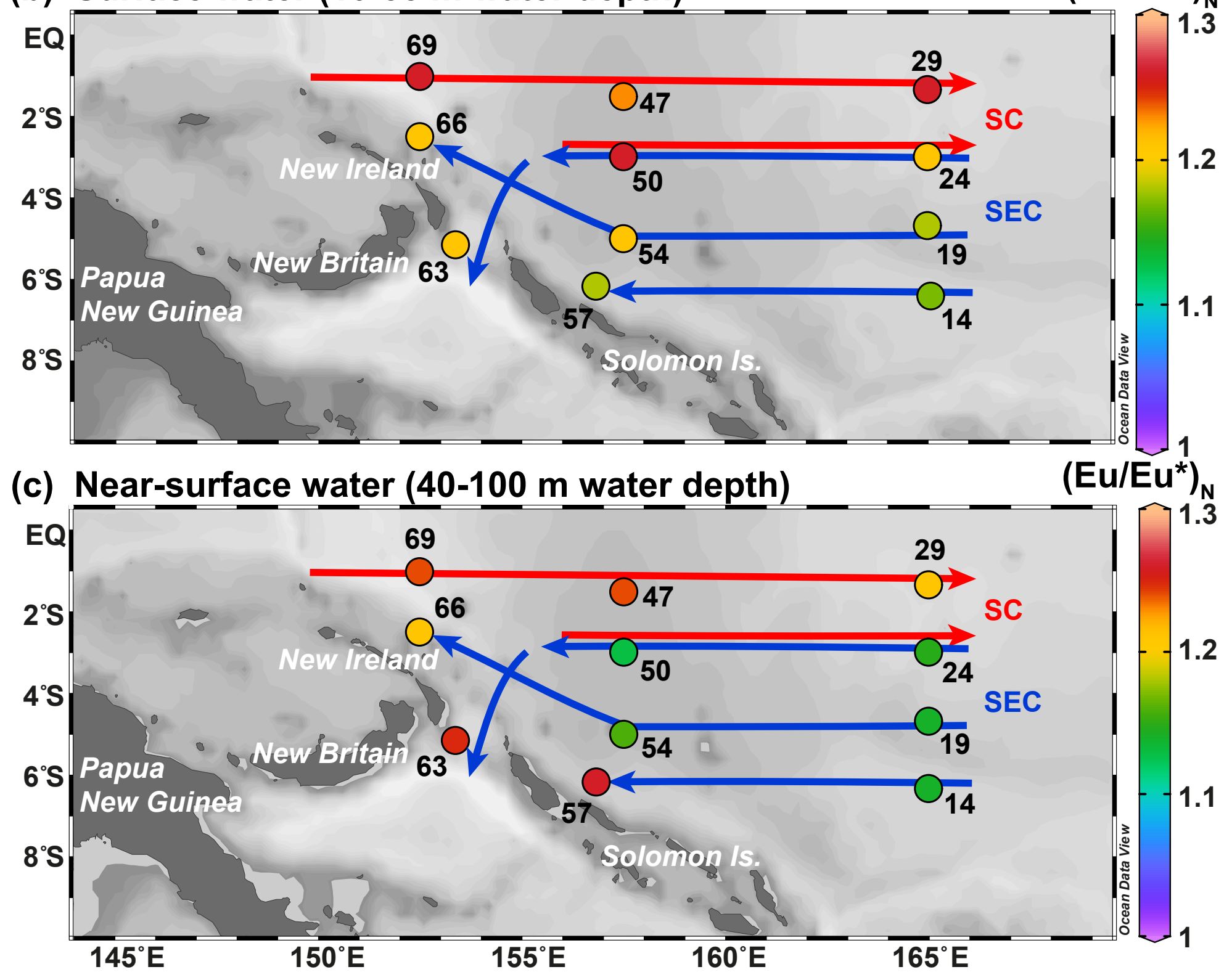


Fi) Surfaç

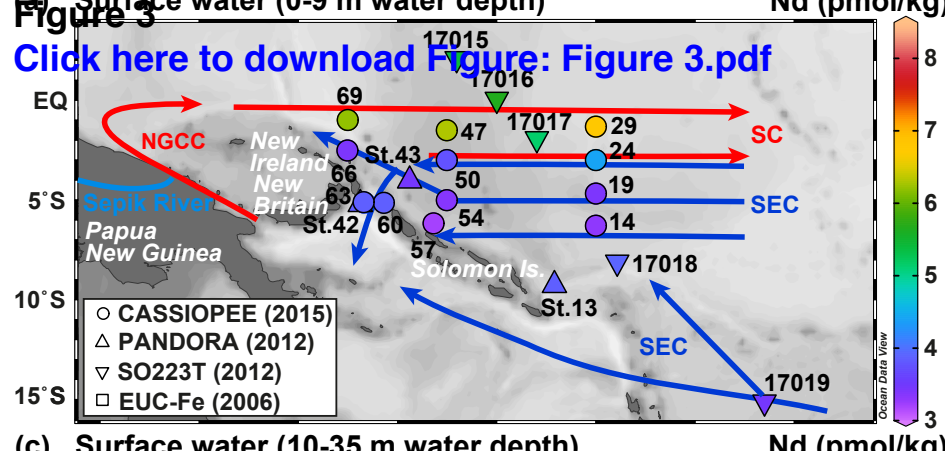

(c) Surface water (10-35 $\mathrm{m}$ water depth)

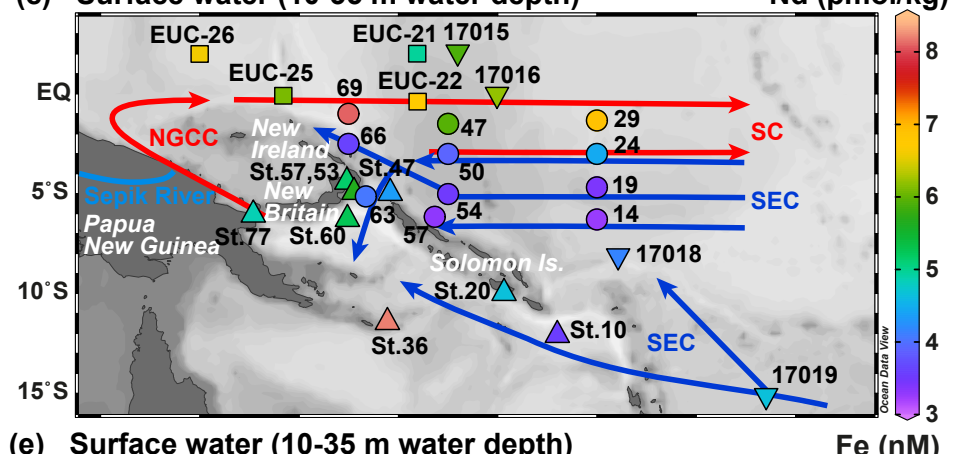

(e) Surface water (10-35 $\mathrm{m}$ water depth)

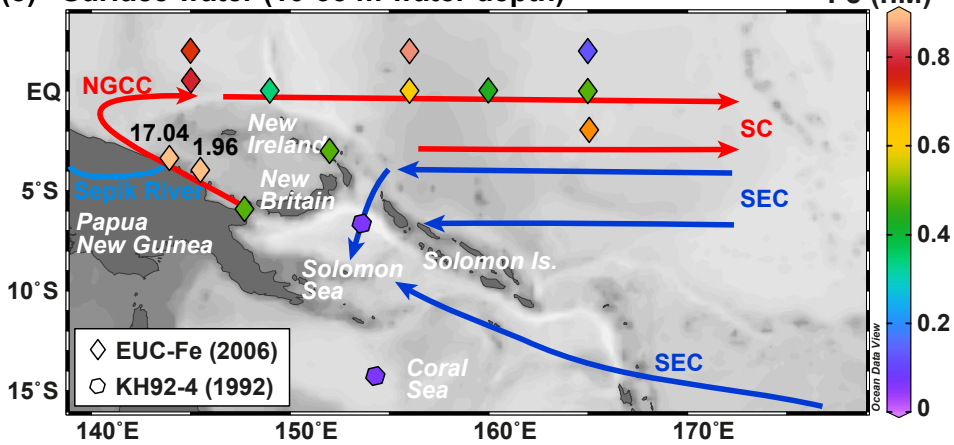

(b) Surface water (0-9 m water depth)

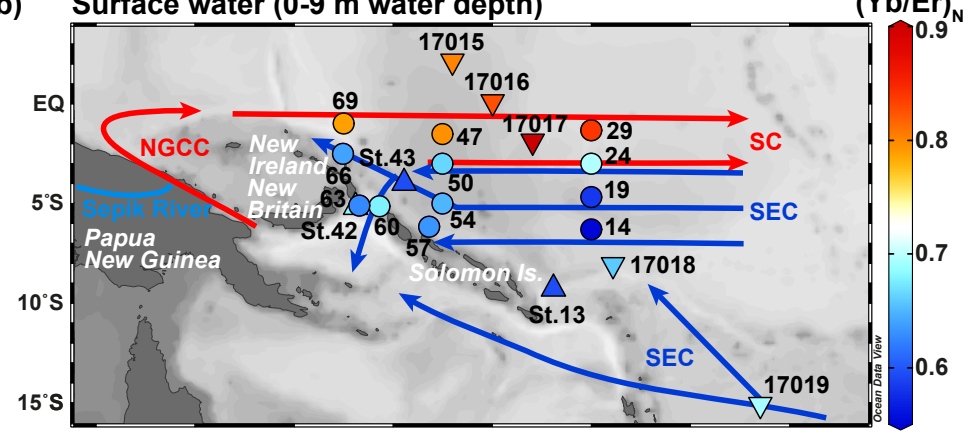

(d) Near-surface water (40-100 m water depth) Nd (pmol/kg)

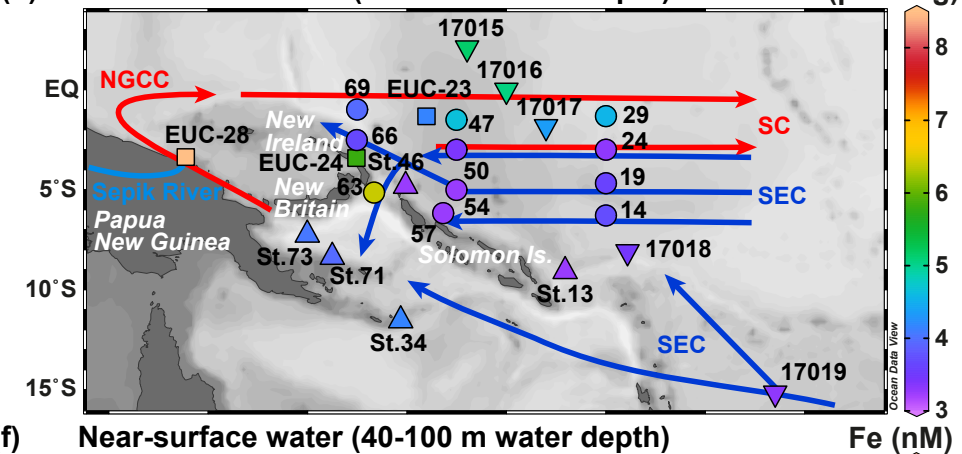

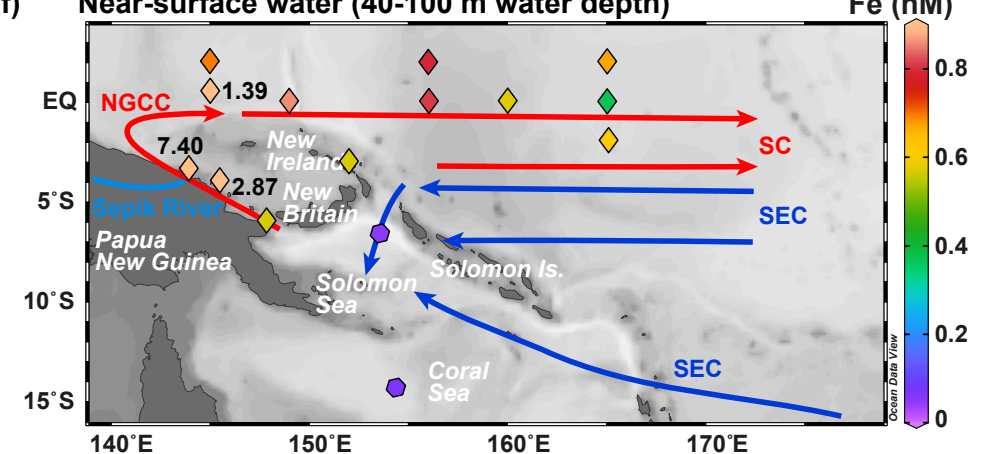


(\$iGufaç 4 water (0-9 m water depth)

Click here to download ${ }_{17916}^{17015}$ : Figure 4.pdf

EQ

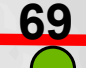

7

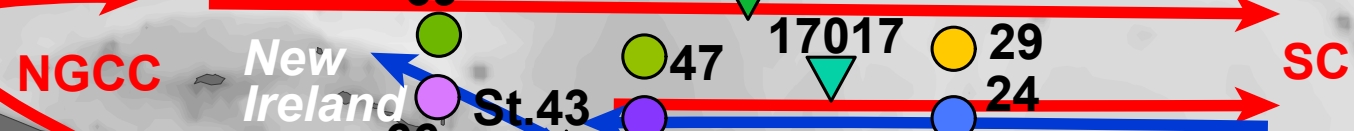

$5^{\circ} \mathrm{S}$

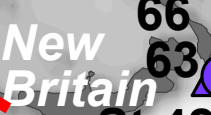

Papua

St.42 60

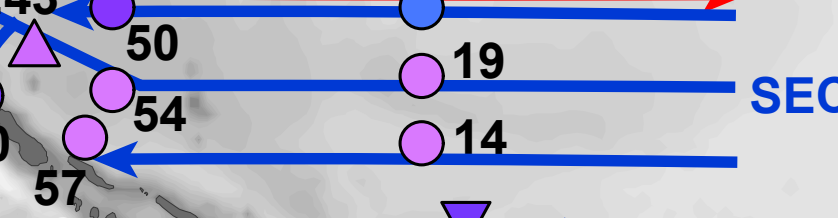

$10^{\circ} \mathrm{S}$

New Guinea

O CASSIOPEE (2015)

$\triangle$ PANDORA (2012)

$\nabla$ SO223T (2012)

$15^{\circ} \mathrm{S} \square \mathrm{EUC}-\mathrm{Fe}(2006)$

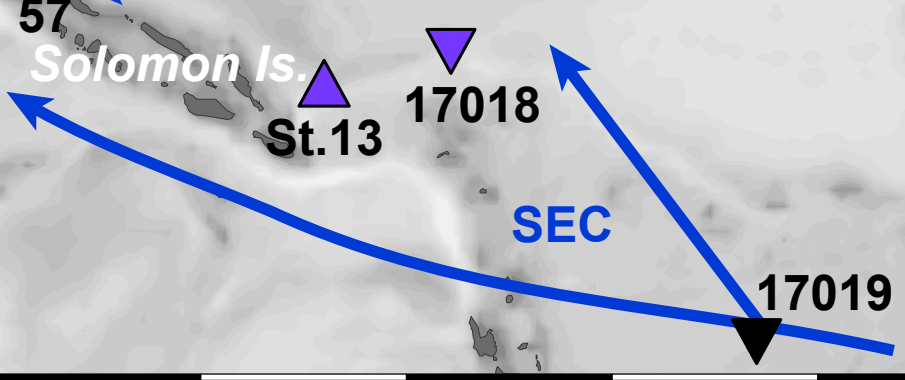

(b) Surface water (10-35 m water depth)

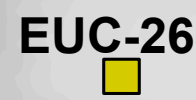

EUC-21 17015

EQ $\quad$ EUC-25 $\quad 69$ EUC-22 17016

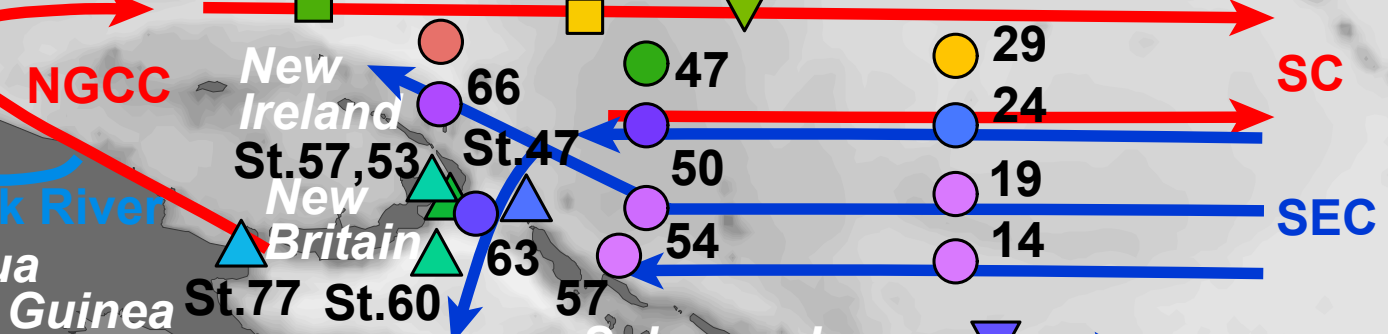

Papua $\triangle$ Britain $\triangle 63$

INew Guinea St.77 St.60 57

$10^{\circ} \mathrm{S}$

$15^{\circ} \mathrm{S}$

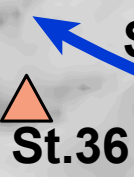

thomon 18

(c) Near-surface water (40-100 m water depth)

019

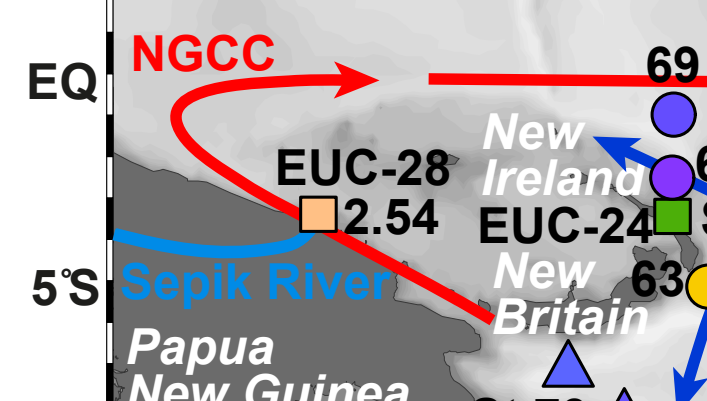

$69-17016$

$$
17015
$$

EUC-23 $\nabla_{17017} \bigcirc^{29}$

.

$$
10
$$

$10^{\circ} \mathrm{S}$

New Guinea $\triangle 4 \checkmark 57$

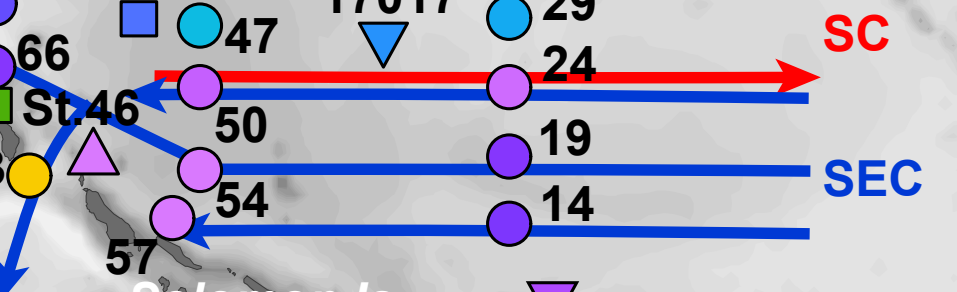


Flguiserface water (0-9 m water depth)

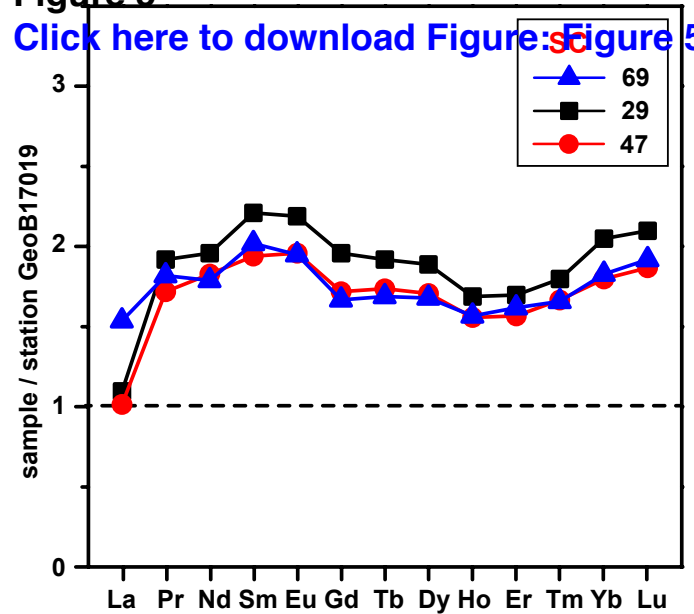

(b) Surface water (10-35 $\mathrm{m}$ water depth)

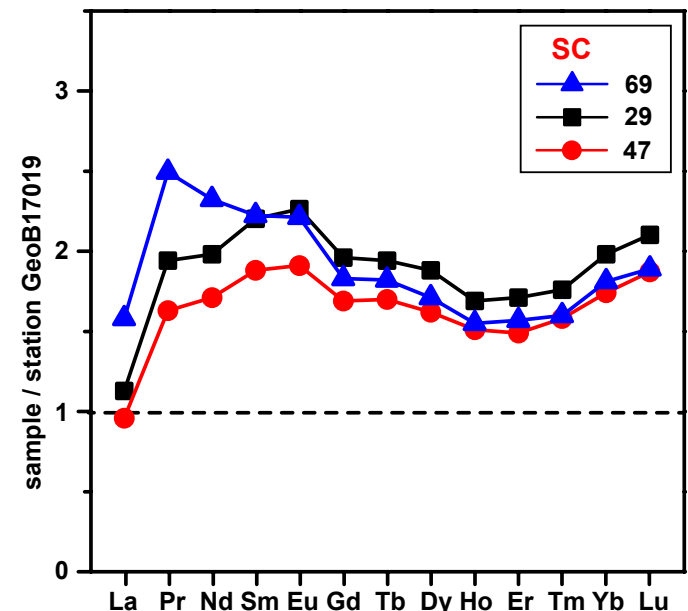

(c) Near-surface water (40-100 m water depth)

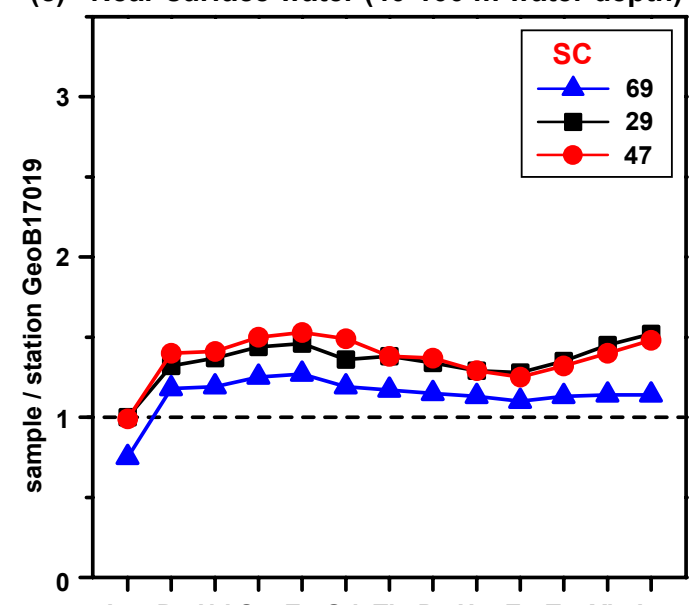

La Pr Nd Sm Eu Gd Tb Dy Ho Er Tm Yb Lu
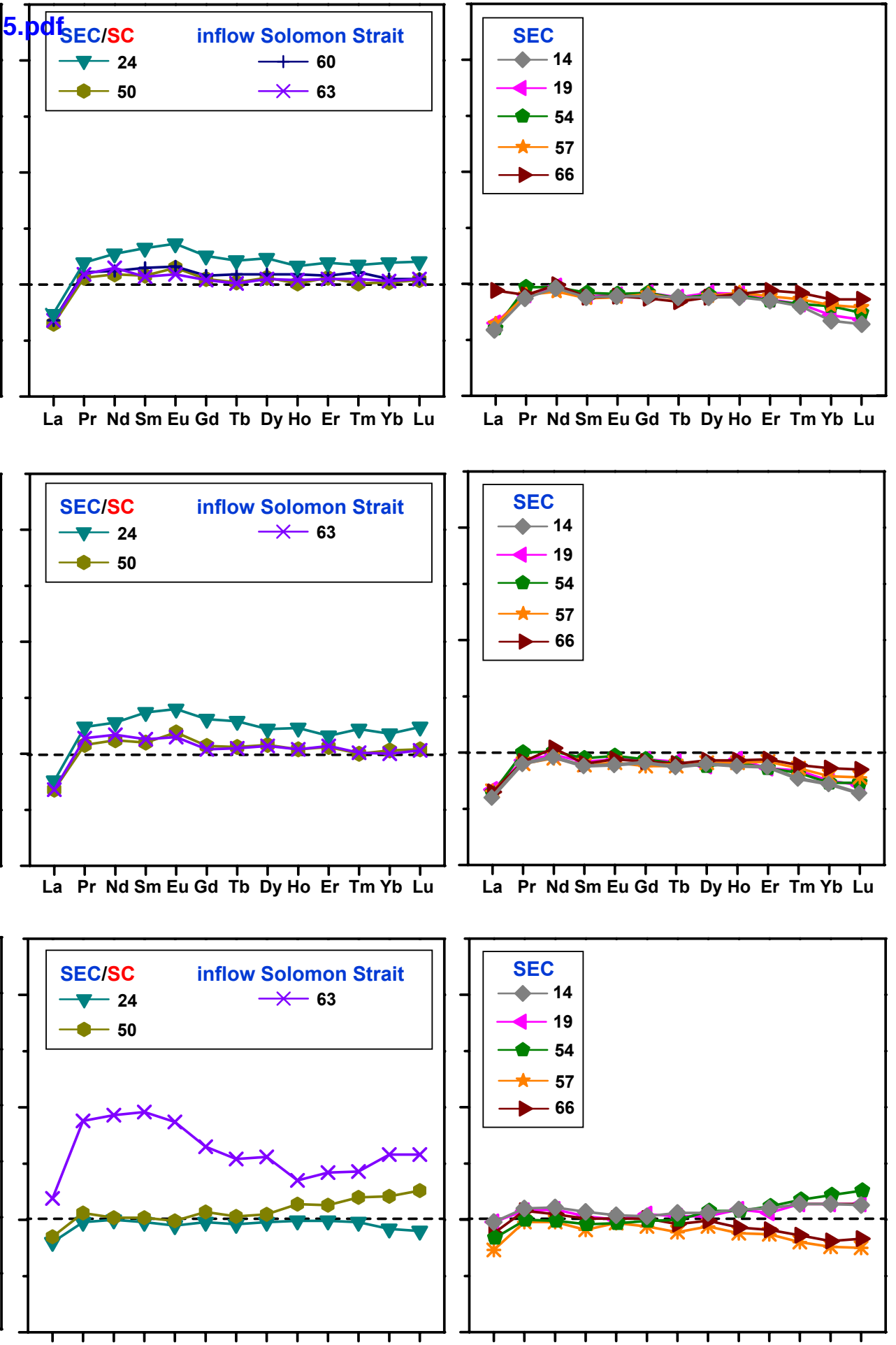

La Pr Nd Sm Eu Gd Tb Dy Ho Er Tm Yb Lu

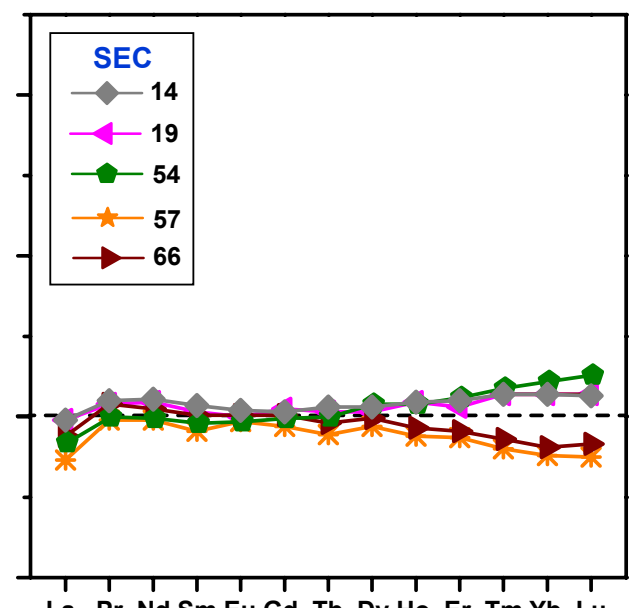

La Pr Nd Sm Eu Gd Tb Dy Ho Er Tm Yb Lu 
(Higsurese water (0-35 m water depth)

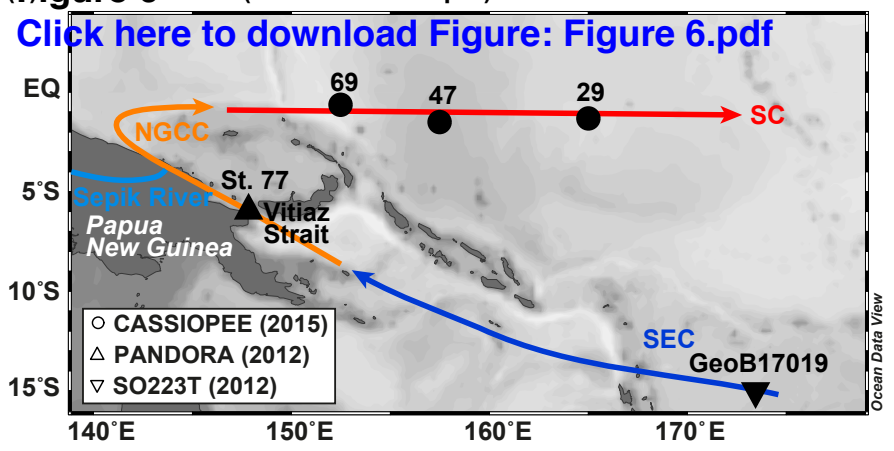

(b)

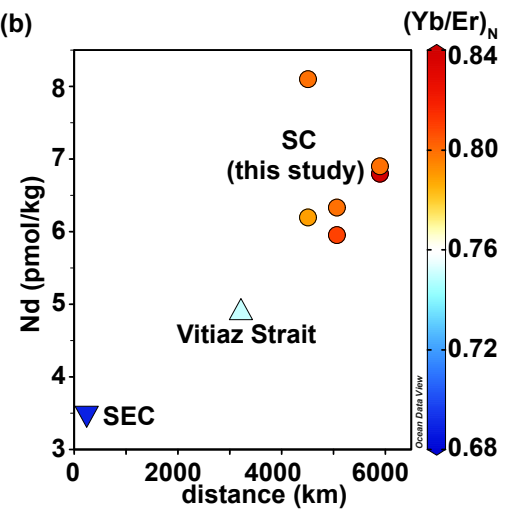

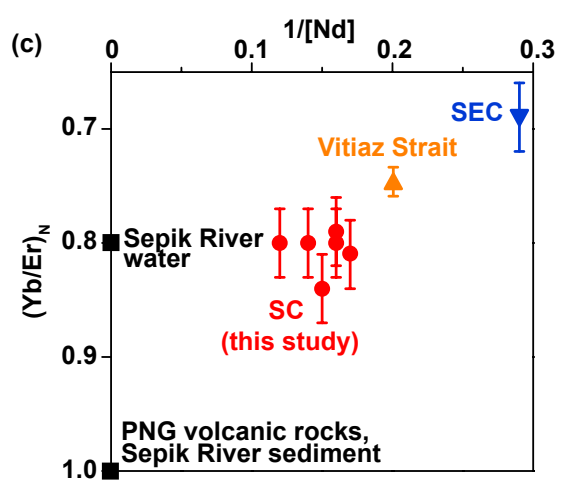


(q) Surface water (0-35 m water depth)

Click here to download Figure: Figure 7.pdf

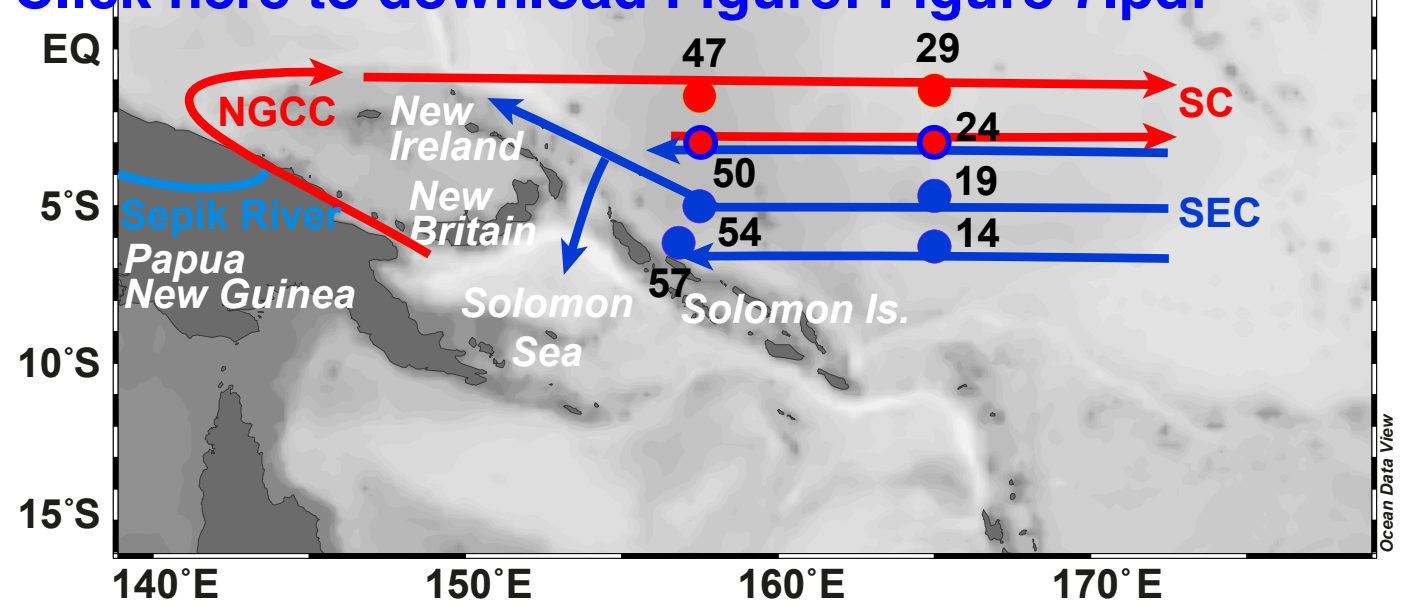

(b)

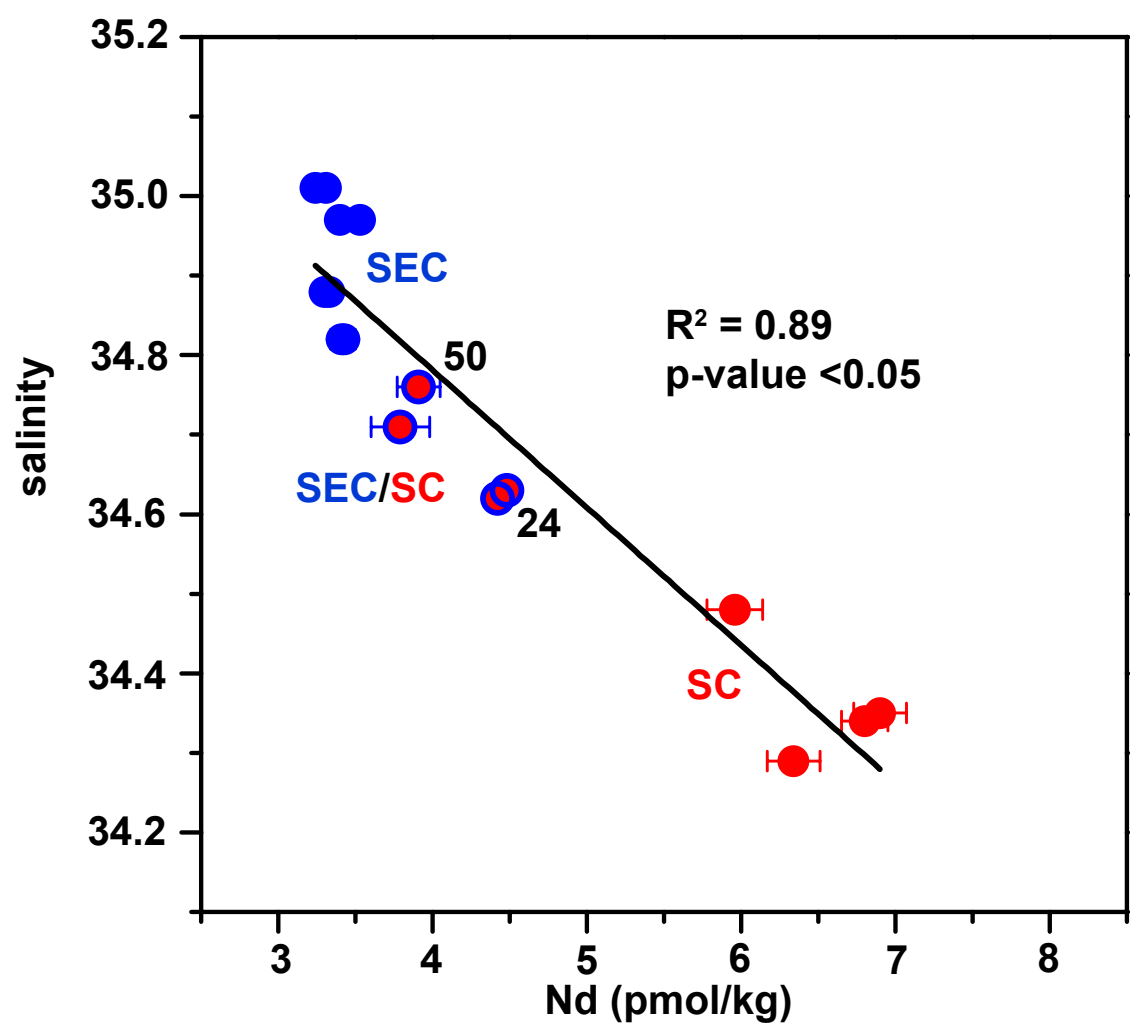

(c)

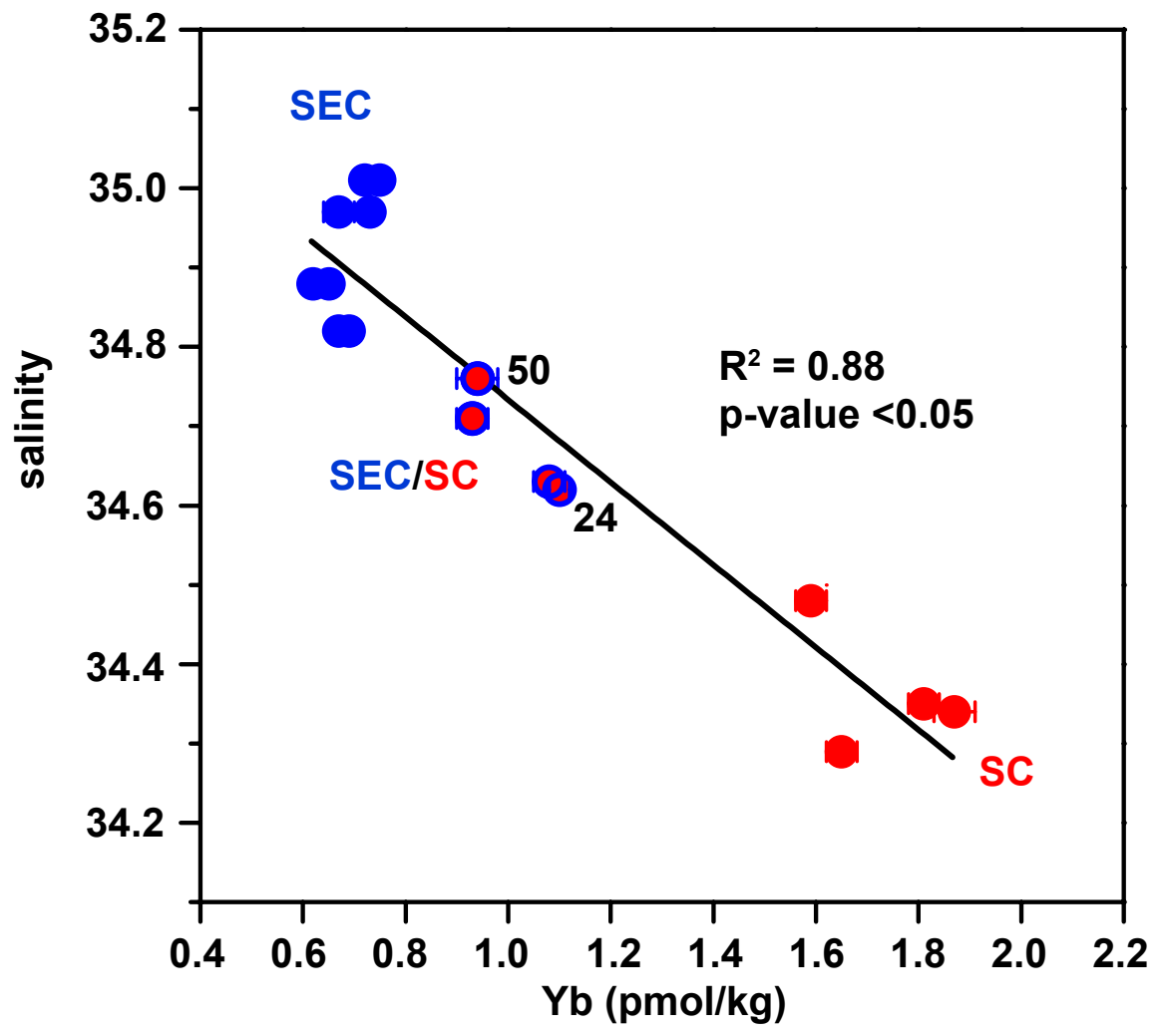




\section{Figure captions}

Fig. 1. (a) Map showing the station locations along the three meridional transects $\left(152.5^{\circ} \mathrm{E}, 157.5^{\circ} \mathrm{E}\right.$, and $165^{\circ} \mathrm{E}$ ) and in the Solomon Strait (stations 60,63$)$ (black dots, this study) of the CASSIOPEE cruise in the tropical West Pacific with eastward and westward currents, identified during the cruise using ADCP data are shown by red and blue arrows, respectively. Published stations mentioned in the text are marked by colored symbols (see legend) (Obata et al., 2008; Slemons et al., 2012; Grenier et al., 2013; Behrens et al., 2018a; Pham et al., 2019). Surface and near-surface currents: Surface Current (SC), South Equatorial Current (SEC), New Guinea Coastal Current (NGCC). This and all maps in following figures were created using Ocean Data View (Schlitzer, 2016). (b, c) Velocity of eastward and westward currents in red and blue colors, respectively, from OSCAR (http://www.oscar.noaa.gov/) product in August 2015 and superimposed in black bold arrows the S-ADCP currents from CASSIOPEE cruise (Delpech et al., 2019) at (b) 10-35 m water depth and (c) 40-100 m water depth. For reference to colors in this figure, the reader is referred to the web version of this article.

Fig. 2. Maps showing the distribution of PAAS-normalized (Taylor and McLennan, 1985) Eu anomalies $\left(\mathrm{Eu} / \mathrm{Eu}^{*}\right)_{\mathrm{N}}$ for surface and near-surface waters of this study within westward (blue arrows) and eastward (red arrows) flowing currents (for abbreviations of currents see Fig. 1). For reference to colors in this figure, the reader is referred to the web version of this article.

Fig. 3. Maps showing the distribution of surface and near-surface water $\mathrm{Nd}$ concentrations (pmol/kg) (a, c, d) and PAAS-normalized (Taylor and McLennan, 1985) $(\mathrm{Yb} / \mathrm{Er})_{\mathrm{N}}$ ratios (b) from this study and published studies, and published total dissolvable Fe (nM) concentrations (e, f) (Obata et al., 2008; Slemons et al., 2012; station EUC-, Grenier et al., 2013; station 170-, Behrens et al., 2018a; station St., Pham et al., 2019) within the westward (blue arrows) and eastward (red arrows) flowing currents identified during the CASSIOPEE cruise using ADCP data. For abbreviations of currents see Fig. 1. For reference to colors in this figure, the reader is referred to the web version of this article.

Fig. 4. Maps showing the distribution of $\mathrm{Nd}$ concentrations normalized to those of upstream station GeoB17019 (Behrens et al., 2018a, black inverted triangle, normalized $\mathrm{Nd}$ concentrations referred to as $\mathrm{Nd}_{\text {norm }}$ ) for all surface and near-surface water samples of this study and published stations (station EUC-, Grenier et al., 2013; station 170-, Behrens et al., 2018a; station St., Pham et al., 2019). For abbreviations of westward (blue) and eastward (red) flowing currents see Fig. 1. For reference to colors in this figure, the reader is referred to the web version of this article.

Fig. 5. REE concentrations normalized to those of upstream station GeoB17019 (Behrens et al., 2018a, black inverted triangle in Fig. 4a-c) for all surface and near-surface water samples of this study. For abbreviations of westward (blue) and eastward (red) flowing currents see Fig. 1. For reference to colors in this figure, the reader is referred to the web version of this article. 
Fig. 6. (a) Map showing stations sampled for surface waters (0-35 $\mathrm{m}$ water depth) along a transect from the SEC (inverted triangle, Behrens et al., 2018a) via the Vitiaz Strait (triangle, Pham et al., 2019) to the SC (dot, this study) (for abbreviations of currents see Fig. 1), and (b) the transect distance $(\mathrm{km}), \mathrm{Nd}$ concentrations and $(\mathrm{Yb} / \mathrm{Er})_{\mathrm{N}}$. (c) Plot of $(\mathrm{Yb} / \mathrm{Er})_{\mathrm{N}}$ vs. $1 /[\mathrm{Nd}]$ of surface waters along the transect with the distance in blue-red color scheme, along with $(\mathrm{Yb} / \mathrm{Er})_{\mathrm{N}}$ of PNG sources (black squares, volcanic rocks, Sepik River water and sediment, Sholkovitz et al., 1999; Woodhead et al, 2010). For abbreviations of currents see Fig. 1. For reference to colors in this figure, the reader is referred to the web version of this article.

Fig. 7. (a) Map showing stations sampled for surface waters (0-35 $\mathrm{m}$ water depth) within westward (blue dots and arrows) and eastward (red dots and arrows) flowing currents (for abbreviations of currents see Fig. 1), and (b, c) plots of salinity vs. $\mathrm{Nd}$ and $\mathrm{Yb}$ concentrations, showing a significant $(p$-value $<0.05)$ correlation that indicates mixing of SC and SEC source waters at stations 24 and 50. For reference to colors in this figure, the reader is referred to the web version of this article. 
Table 1

Click here to download Table: Table 1.docx

Table 1

Dissolved REE concentrations ( $\mathrm{pmol} / \mathrm{kg}$ ) of seawater samples of this study.

\begin{tabular}{|c|c|c|c|c|c|c|c|c|c|c|c|c|c|c|c|}
\hline $\begin{array}{l}\text { Sample } \\
\text { ID }\end{array}$ & $\begin{array}{l}\text { Water } \\
\text { depth } \\
\text { (m) }\end{array}$ & La & $\mathrm{Ce}$ & Pr & Nd & Sm & $\mathbf{E u}$ & Gd & $\mathbf{T b}$ & Dy & Ho & $\mathbf{E r}$ & $\mathbf{T m}$ & $\mathbf{Y b}$ & Lu \\
\hline \multicolumn{16}{|c|}{ Station $14\left(6.3328^{\circ} \mathrm{S}, 165.0002^{\circ} \mathrm{E}\right)$} \\
\hline $1-7+8$ & 6.7 & 3.10 & 1.37 & 0.69 & 3.33 & 0.66 & 0.20 & 1.17 & 0.18 & 1.40 & 0.37 & 1.17 & 0.14 & 0.62 & 0.09 \\
\hline $1-5+6$ & 29 & 3.09 & 1.38 & 0.70 & 3.30 & 0.65 & 0.20 & 1.19 & 0.18 & 1.42 & 0.36 & 1.19 & 0.13 & 0.65 & 0.09 \\
\hline $1-3+4$ & 94 & 3.92 & 1.53 & 0.80 & 3.72 & 0.74 & 0.23 & 1.27 & 0.21 & 1.63 & 0.46 & 1.54 & 0.20 & 1.07 & 0.16 \\
\hline \multicolumn{16}{|c|}{ Station $19\left(4.6660^{\circ} \mathrm{S}, 164.9987^{\circ} \mathrm{E}\right)$} \\
\hline $1-7+8$ & 6 & 3.37 & 1.49 & 0.71 & 3.43 & 0.67 & 0.21 & 1.22 & 0.18 & 1.46 & 0.38 & 1.19 & 0.14 & 0.67 & 0.10 \\
\hline $1-5+6$ & 26 & 3.49 & 1.52 & 0.73 & 3.41 & 0.69 & 0.21 & 1.24 & 0.19 & 1.40 & 0.39 & 1.19 & 0.15 & 0.69 & 0.10 \\
\hline $1-3+4$ & 60 & 3.91 & 1.96 & 0.79 & 3.63 & 0.72 & 0.22 & 1.29 & 0.20 & 1.58 & 0.46 & 1.49 & 0.20 & 1.06 & 0.17 \\
\hline \multicolumn{16}{|c|}{ Station $24\left(3.0007^{\circ} \mathrm{S}, 165.0022^{\circ} \mathrm{E}\right)$} \\
\hline $1-7+8$ & 6 & 3.84 & 2.38 & 0.94 & 4.42 & 0.99 & 0.31 & 1.65 & 0.25 & 1.96 & 0.49 & 1.64 & 0.20 & 1.10 & 0.17 \\
\hline $1-5+6$ & 26 & 3.96 & 2.31 & 0.98 & 4.48 & 1.02 & 0.32 & 1.73 & 0.26 & 1.94 & 0.52 & 1.60 & 0.21 & 1.08 & 0.17 \\
\hline $1-3+4$ & 71 & 3.21 & 1.26 & 0.71 & 3.33 & 0.68 & 0.21 & 1.21 & 0.19 & 1.50 & 0.41 & 1.38 & 0.17 & 0.86 & 0.13 \\
\hline \multicolumn{16}{|c|}{ Station $29\left(1.3338^{\circ} \mathrm{S}, 165.0032^{\circ} \mathrm{E}\right)$} \\
\hline $1-7+8$ & 9 & 5.67 & 4.12 & 1.51 & 6.80 & 1.65 & 0.50 & 2.58 & 0.40 & 3.00 & 0.70 & 2.33 & 0.30 & 1.87 & 0.29 \\
\hline $1-5+6$ & 25 & 5.90 & 4.20 & 1.53 & 6.90 & 1.64 & 0.51 & 2.59 & 0.40 & 3.00 & 0.71 & 2.37 & 0.30 & 1.81 & 0.29 \\
\hline $1-3+4$ & 89 & 4.01 & 2.40 & 0.96 & 4.56 & 1.00 & 0.32 & 1.68 & 0.27 & 2.05 & 0.54 & 1.79 & 0.24 & 1.36 & 0.22 \\
\hline \multicolumn{16}{|c|}{ Station $47\left(1.4987^{\circ} \mathrm{S}, 157.5003^{\circ} \mathrm{E}\right)$} \\
\hline $2-15+16$ & 4.4 & 5.26 & 3.77 & 1.35 & 6.34 & 1.45 & 0.45 & 2.25 & 0.36 & 2.70 & 0.65 & 2.16 & 0.28 & 1.65 & 0.26 \\
\hline $2-11+12$ & 25 & 5.02 & 3.35 & 1.28 & 5.96 & 1.40 & 0.43 & 2.23 & 0.35 & 2.58 & 0.63 & 2.05 & 0.27 & 1.59 & 0.26 \\
\hline $2-6+7$ & 60 & 3.97 & 2.48 & 1.02 & 4.69 & 1.04 & 0.33 & 1.84 & 0.27 & 2.09 & 0.54 & 1.75 & 0.23 & 1.31 & 0.22 \\
\hline \multicolumn{16}{|c|}{ Station $50\left(3.0012^{\circ} \mathrm{S}, 157.5003^{\circ} \mathrm{E}\right)$} \\
\hline $1-7+8$ & 4 & 3.38 & 1.92 & 0.84 & 3.79 & 0.81 & 0.26 & 1.38 & 0.21 & 1.69 & 0.43 & 1.46 & 0.17 & 0.93 & 0.15 \\
\hline $1-5+6$ & 24 & 3.56 & 1.76 & 0.85 & 3.91 & 0.82 & 0.27 & 1.41 & 0.22 & 1.72 & 0.44 & 1.47 & 0.17 & 0.94 & 0.15 \\
\hline $1-3+4$ & 55 & 3.40 & 1.44 & 0.77 & 3.42 & 0.71 & 0.22 & 1.32 & 0.20 & 1.61 & 0.48 & 1.58 & 0.21 & 1.13 & 0.18 \\
\hline \multicolumn{16}{|c|}{ Station $54\left(4.9988^{\circ} \mathrm{S}, 157.4995^{\circ} \mathrm{E}\right)$} \\
\hline $1-9+10$ & 5 & 3.13 & 1.54 & 0.76 & 3.40 & 0.69 & 0.21 & 1.21 & 0.18 & 1.44 & 0.38 & 1.18 & 0.14 & 0.73 & 0.10 \\
\hline $1-7+8$ & 24 & 3.35 & 1.70 & 0.79 & 3.53 & 0.71 & 0.22 & 1.24 & 0.18 & 1.41 & 0.38 & 1.19 & 0.14 & 0.67 & 0.10 \\
\hline $1-5+6$ & 74 & 3.35 & 1.46 & 0.73 & 3.30 & 0.67 & 0.21 & 1.22 & 0.20 & 1.66 & 0.45 & 1.56 & 0.21 & 1.14 & 0.18 \\
\hline \multicolumn{16}{|c|}{ Station $57\left(6.1663^{\circ} \mathrm{S}, 156.8328^{\circ} \mathrm{E}\right)$} \\
\hline $1-7+8$ & 6 & 3.32 & 1.33 & 0.71 & 3.24 & 0.66 & 0.20 & 1.21 & 0.18 & 1.42 & 0.39 & 1.23 & 0.15 & 0.75 & 0.11 \\
\hline $1-5+6$ & 10 & 3.45 & 1.30 & 0.71 & 3.31 & 0.66 & 0.21 & 1.16 & 0.18 & 1.44 & 0.38 & 1.27 & 0.15 & 0.72 & 0.11 \\
\hline $1-3+4$ & 45 & 2.94 & 1.37 & 0.71 & 3.26 & 0.64 & 0.21 & 1.16 & 0.18 & 1.44 & 0.37 & 1.22 & 0.14 & 0.71 & 0.11 \\
\hline \multicolumn{16}{|c|}{ Station $60\left(5.1417^{\circ} \mathrm{S}, 154.3325^{\circ} \mathrm{E}\right)$} \\
\hline $1-21+22$ & 8 & 3.54 & 2.45 & 0.88 & 3.90 & 0.86 & 0.27 & 1.43 & 0.23 & 1.74 & 0.46 & 1.49 & 0.19 & 0.97 & 0.15 \\
\hline \multicolumn{16}{|c|}{ Station $63\left(5.1378^{\circ} \mathrm{S}, 153.3665^{\circ} \mathrm{E}\right)$} \\
\hline $1-7+8$ & 6 & 3.55 & 2.30 & 0.86 & 4.01 & & & & & 1.66 & & & 0.18 & 0.94 & 0.15 \\
\hline $1-5+6$ & 26 & 3.55 & 2.53 & 0.90 & 4.07 & 0.84 & 0.26 & 1.37 & 0.21 & 1.71 & 0.44 & 1.48 & 0.17 & 0.91 & 0.14 \\
\hline $1-3+4$ & 51 & 4.77 & $5.9^{*}$ & 1.37 & 6.44 & 1.36 & 0.41 & 2.02 & 0.30 & 2.39 & 0.57 & 1.98 & 0.25 & 1.47 & 0.23 \\
\hline \multicolumn{16}{|c|}{ Station $66\left(2.4983^{\circ} \mathrm{S}, 152.4945^{\circ} \mathrm{E}\right)$} \\
\hline $1-17+18$ & 4 & 4.92 & 1.99 & 0.71 & 3.45 & 0.66 & 0.20 & 1.15 & 0.18 & 1.41 & & 1.29 & 0.16 & 0.79 & 0.12 \\
\hline $1-15+16$ & 10 & 3.26 & 1.35 & 0.73 & 3.82 & 0.66 & 0.21 & 1.24 & 0.18 & 1.46 & 0.39 & 1.26 & 0.15 & 0.77 & 0.12 \\
\hline $1-9+10$ & 25 & 3.49 & 1.76 & 0.73 & 3.46 & 0.69 & 0.21 & 1.18 & 0.18 & 1.51 & 0.39 & 1.33 & 0.15 & 0.79 & 0.12 \\
\hline $1-7+8$ & 51 & 3.54 & 1.80 & 0.79 & 3.49 & 0.70 & 0.22 & 1.24 & 0.19 & 1.52 & 0.39 & 1.27 & 0.15 & 0.76 & 0.12 \\
\hline $1-1+2$ & 100 & 4.88 & 2.49 & 0.88 & 3.83 & 0.77 & 0.25 & 1.35 & 0.21 & 1.74 & 0.49 & 1.62 & 0.22 & 1.24 & 0.21 \\
\hline \multicolumn{16}{|c|}{ Station $69\left(0.9993^{\circ} \mathrm{S}, 152.5010^{\circ} \mathrm{E}\right)$} \\
\hline $1-7+8$ & 6 & 8.01 & 4.32 & 1.43 & 6.20 & 1.51 & 0.45 & 2.19 & 0.35 & 2.66 & 0.65 & 2.22 & 0.28 & 1.68 & 0.27 \\
\hline $1-5+6$ & 25 & 8.27 & $10^{*}$ & 1.96 & 8.10 & 1.66 & 0.50 & 2.42 & 0.37 & 2.73 & 0.65 & 2.16 & 0.28 & 1.65 & 0.26 \\
\hline $1-3+4$ & 56 & 3.00 & 2.05 & 0.86 & 3.96 & 0.87 & 0.28 & 1.47 & 0.23 & 1.75 & 0.47 & 1.54 & 0.20 & 1.07 & 0.17 \\
\hline
\end{tabular}

